\title{
REGULATION OF FIXED INCOME SECURITIES MARKETS IN THE UNITED STATES
}

\author{
FELICE B. FRIEDMAN* \\ (This paper describes the regulatory framework as of December 2003)
}

\begin{abstract}
This paper looks at the development and regulation of the fixed income securities market in the United States. The US fixed income market is one of the oldest and most developed debt markets in the world. It is also one of the most heterogeneous, with the four key market segments - government securities, the securities of government sponsored enterprises, municipal securities, and corporate debt securities - all being relatively large and deep. This paper describes the evolution of fixed income market regulation in the United States, discussing both primary and secondary market regulation. The paper also looks at market integrity issues and the enforcement authority of the US Securities and Exchange Commission, which is unusually broad and has played an important role in the effectiveness of its regulation. The paper concludes that the fact that the US fixed income market flourished for many years in the absence of regulation must be seen in a broader legal and regulatory context. While the debt market itself may have been unregulated, it operated within a larger framework of equity market regulation and enforcement, complemented by a long history of bank supervision, that had a significant impact on its development. It is this context that permitted US authorities to adopt regulation in stages, in response to differing demands and priorities. The dynamic nature of the regulation of the US fixed income market - its development in response to market crises -- underscores the need for regulation to remain responsive to market developments, and to be adapted to domestic constraints.
\end{abstract}

JEL Classification Code: G18, K22

Keywords: Debt Markets, Fixed Income Securities, Regulation, Supervision

World Bank Policy Research Working Paper 3283, April 2004

The Policy Research Working Paper Series disseminates the findings of work in progress to encourage the exchange of ideas about development issues. An objective of the series is to get the findings out quickly, even if the presentations are less than fully polished. The papers carry the names of the authors and should be cited accordingly. The findings, interpretations, and conclusions expressed in this paper are entirely those of the authors. They do not necessarily represent the view of the World Bank, its Executive Directors, or the countries they represent. Policy Research Working Papers are available online at http://econ.worldbank.org.

\footnotetext{
*Felice Friedman (ffriedman@worldbank.org) is from the World Bank’s Financial Sector Vice Presidency. The author wishes to thank Jeppe Ladekarl, Dimitri Vittas and Claire Grose of the Financial Sector Operations and Policy Department for their assistance and support in the research and preparation of this paper, the other members of the Department for their comments, and Robert D. Strahota of the U.S. Securities and Exchange Commission for his thoughts and suggestions.
} 


\section{Table of Contents}

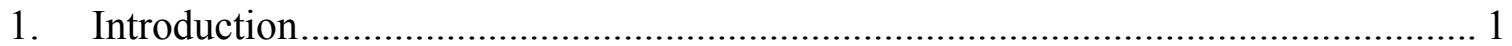

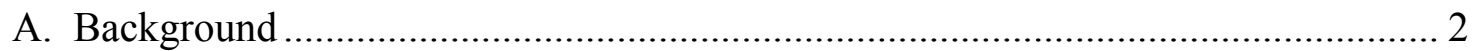

B. Snapshot of Fixed Income Market - Types of Issuers ....................................... 2

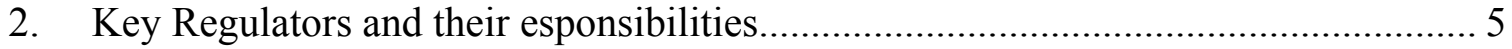

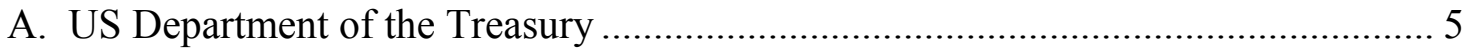

B. Federal Reserve System ................................................................................... 6

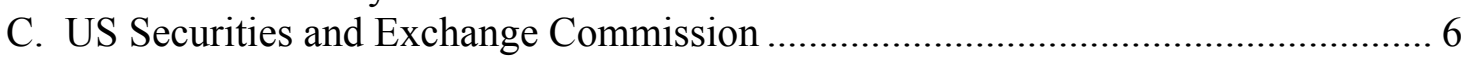

D. Office of Federal Housing Enterprise Oversight (OFHEO) .................................. 7

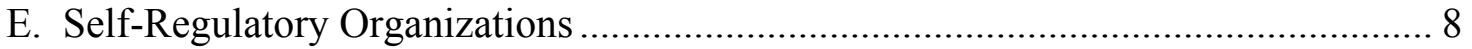

3. Development and Regulatory Framework of the US Fixed Income Market ............ 10

A. Development of US Debt Markets....................................................................... 10

B. Framework for Regulation of US Debt Markets ............................................. 13

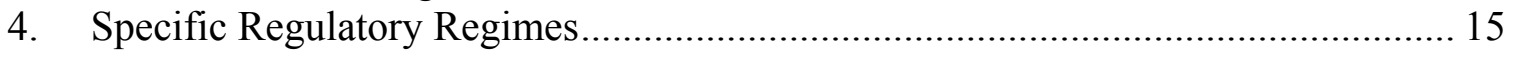

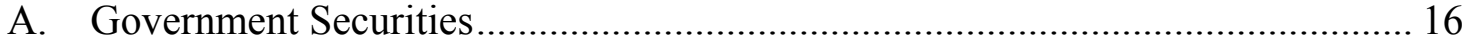

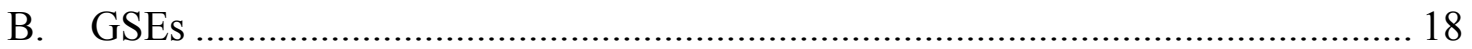

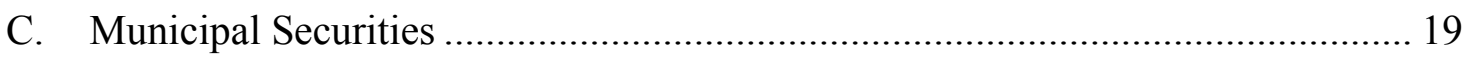

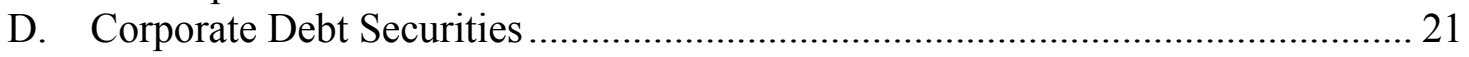

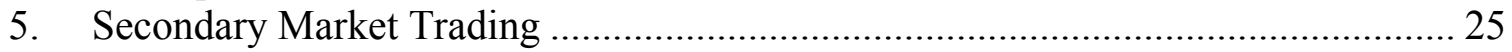

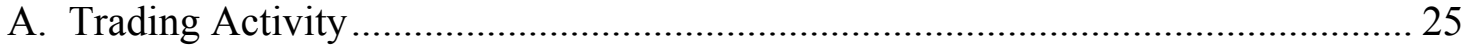

B. Regulation and Disclosure in the Secondary Markets ........................................ 27

C. Transparency in the Secondary Market................................................................. 33

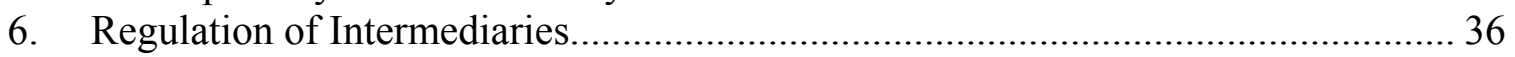

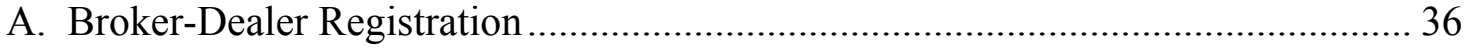

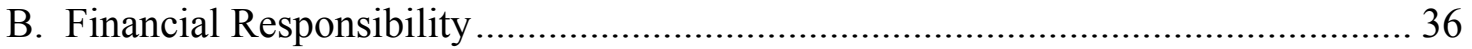

C. Customer Protection Rules ............................................................................... 37

D. Sales Practice Rules .......................................................................................... 37

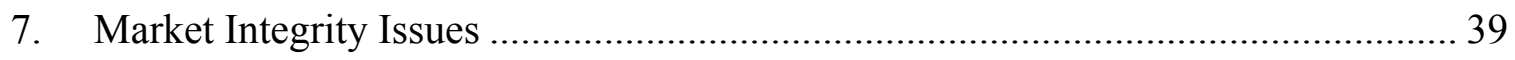

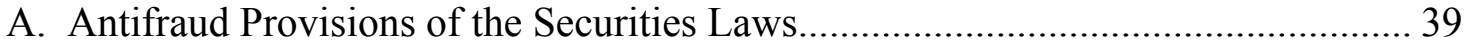

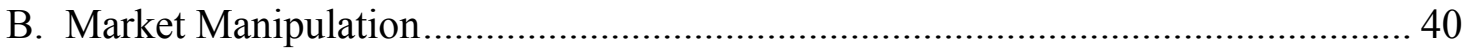

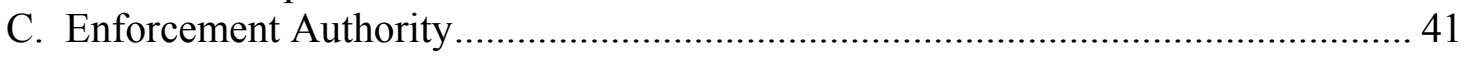

8. Regulation of Market Infrastructure ................................................................. 42

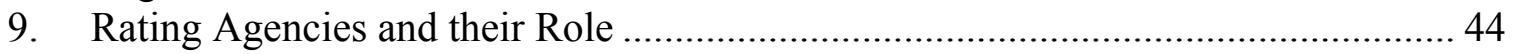

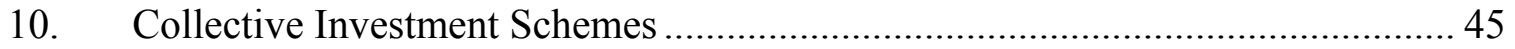

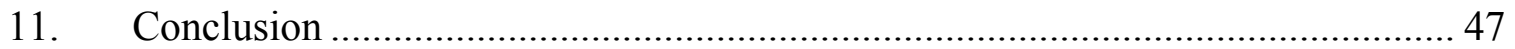

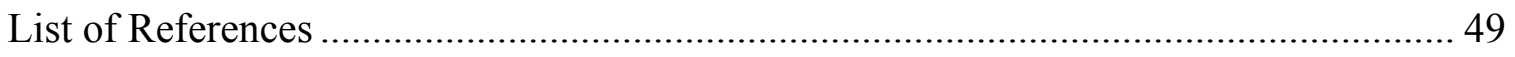




\section{INTRODUCTION}

This study describes the regulatory framework of the fixed income securities market in the United States. While such regulation is relatively uniform, particularly when compared to securities market regulation in the European Union, there are nevertheless a number of different regulatory schemes that apply. In the United States, regulation of the fixed income securities market may vary depending on: (i) the nature of the issuer (e.g., federal government, municipal, corporate); (ii) the nature of the instrument (short, long term); (iii) how the securities are offered (publicly or privately); and (iv) the nature of the market (exchange, alternative trading system, or over-thecounter). Moreover, while the United States has a single federal securities regulator, the US Securities and Exchange Commission, additional government agencies and regulators play important roles in the US fixed income market.

This report discusses the development and regulation of the US fixed income securities market. After providing some brief background about the market, the report gives an overview of the key regulators who are responsible for its oversight. The report then discusses the market's development and regulation, focusing on its unique characteristics and constraints. As will be seen, US regulation is premised on the basic foundation that all offers of securities to the public should be regulated, unless specifically exempted. While corporate debt securities are thus comprehensively regulated, the other key segments of the US fixed income market -- government securities, the securities of government sponsored enterprises, and municipal securities -have traditionally been exempt from regulation in the United States. The report will discuss the reasons for these exemptions, and how and why they have eroded over time. Moreover, the report will also describe how the secondary market in these securities has been regulated, including, importantly, the regulation of intermediaries, which, while not unique to the fixed-income market, has been particularly important in the absence of traditional primary offer regulation. Market integrity issues, including insider trading and market manipulation, also are discussed, along with a description of the SEC's enforcement authority which is unusually broad and plays an extremely important role in the effectiveness of its regulation. The report then looks at issues of market infrastructure, focusing especially on problems that developed in the government debt market following the events of September 11, 2001. Finally, the report concludes with a brief discussion of the concerns currently being raised about the role and regulation of rating agencies, and gives an overview, as well, of some of the issues relating to the regulation of bond funds.

The US regulatory system is unique. Its structure and effectiveness are grounded in the legal and financial history and development of the United States. This is not to say that aspects of US regulation could not be relevant to other markets. After all, the United States was an emerging market not all that long ago, and its approach to regulation - both positive and negative - may contain useful insights for emerging markets. Nevertheless, as will be seen, the US regulatory approach could not be lifted wholesale and applied to

other markets. What may seem to be particularly effective regulation in the United States 
may be due to its links to other parts of the legal and financial infrastructure, and thus may not work well, or indeed, at all, in a different environment.

\section{A. BACKGROUND}

According to the Bond Market Association (BMA) ${ }^{1}$, the United States supported a $\$ 20.2$ trillion market in outstanding debt securities at the end of 2002. This was nearly double the $\$ 11.7$ trillion market for US stocks. The market in outstanding debt securities was divided roughly as shown in Table 1.

Table 1: US Debt Market Data, 2002

\begin{tabular}{|c|c|c|c|c|c|c|c|c|c|}
\hline & \multicolumn{2}{|c|}{ Amount outstanding } & \multicolumn{2}{|c|}{ New Issuance } & \multicolumn{2}{|c|}{$\begin{array}{l}\text { Average Daily } \\
\text { Trading Volume }\end{array}$} & \multicolumn{2}{|c|}{$\begin{array}{l}\text { Annual Trading } \\
\text { Volume }\end{array}$} & \multirow{2}{*}{$\begin{array}{l}\text { Turnover } \\
/ 3 \\
\%\end{array}$} \\
\hline & $\begin{array}{l}\text { USD } \\
\text { Billion }\end{array}$ & $\begin{array}{l}\% \text {-of } \\
\text { GDP }\end{array}$ & $\begin{array}{l}\text { USD } \\
\text { Billion }\end{array}$ & $\begin{array}{l}\% \text {-of } \\
\text { GDP }\end{array}$ & $\begin{array}{l}\text { USD } \\
\text { Billion }\end{array}$ & $\begin{array}{l}\% \text {-of } \\
\text { GDP }\end{array}$ & $\begin{array}{l}\text { USD } \\
\text { Billion }\end{array}$ & $\begin{array}{l}\% \text {-of } \\
\text { GDP }\end{array}$ & \\
\hline $\begin{array}{l}\text { US } \\
\text { Treasuries } \\
/ 1\end{array}$ & 3205 & 30.7 & 572 & 5.5 & 366 & 3.5 & 92,333 & 883.9 & 2,881 \\
\hline $\begin{array}{l}\text { Federal } \\
\text { Agency } \\
\text { Debt }\end{array}$ & 2359 & 22.6 & 1710 & 16.4 & 82 & 0.8 & 20,614 & 197.3 & 874 \\
\hline $\begin{array}{l}\text { Municipal } \\
\text { Securities }\end{array}$ & 1784 & 17.1 & 431 & 4.1 & 11 & 0.1 & $2,696.4$ & 25.8 & 151 \\
\hline $\begin{array}{l}\text { Corporate } \\
\text { Debt }\end{array}$ & 3997 & 38.3 & 594 & 5.7 & 20 & 0.2 & 5,141 & 49.2 & 129 \\
\hline $\begin{array}{l}\text { Mortgage } \\
\text { Related } \\
\text { Securities /2 }\end{array}$ & 4705 & 45.0 & 2310 & 22.1 & 155 & 1.5 & 38,934 & 372.7 & 828 \\
\hline $\begin{array}{l}\text { Asset- } \\
\text { Backed } \\
\text { securities }\end{array}$ & 1543 & 14.8 & 485 & 4.6 & NA & & NA & & \\
\hline Total & 17593 & 168.4 & 6102 & 58.4 & 634 & 6.1 & 159718 & 1529.0 & 908 \\
\hline $\begin{array}{l}\text { Memo: GDP } \\
\text { Notes: } \\
\text { /1: Gross cou } \\
\text { /2: Includes } \\
\text { /3: Turnover }\end{array}$ & $\begin{array}{l}\text { D } 10446 \\
\text { issuanc } \\
\text { cy and p } \\
\text { sured as }\end{array}$ & $\begin{array}{l}\text { e-label p } \\
\text { nual Tra }\end{array}$ & throughs & 2: 252 & & & & & \\
\hline
\end{tabular}

Particularly notable during 2002 was the tremendous growth in the mortgage-related securities market.

\section{B. SNAPSHOT OF FiXed INCOME MARKET - TyPES OF ISSUERS}

The four key segments of the fixed income market in the United States are the federal government, the federal agencies and government sponsored enterprises, the municipalities, and US domestic corporations.

\footnotetext{
${ }^{1}$ The statistics included in this section of the Report are taken from the Bond Market Association (www.bondmarkets.com), unless otherwise noted. Figures have been rounded as well as estimated so may not total 100 percent.
} 
1. US Treasury securities: According to the Federal Reserve Bulletin, the US government securities market is the largest and most active debt market in the world. $^{2}$ In 2002, there were over $\$ 3$ trillion in direct US government securities outstanding, not including debt instruments issued by US federal agencies and government sponsored enterprises.

US Treasury securities comprise Treasury bills (which have a maturity of one year or less), Treasury notes (which have a medium-term maturity of between one and ten years), and Treasury bonds (which have a maturity of more than 10 years).

2. Federal government agencies and federally sponsored debt: The total issuance of long-term debt securities by federal government agencies and government sponsored enterprises amounted to just over $\$ 1$ trillion in 2002 . $^{3}$ The Government National Mortgage Association (Ginnie Mae) is a wholly-owned federal government corporation, and its guarantees are backed by the full faith and credit of the US government. The Federal National Mortgage Association (Fannie Mae) and The Federal Home Loan Mortgage Association (Freddie Mac) are government sponsored enterprises. They are publicly chartered entities that are privately owned and operated, and their guarantees are not backed by the US government. Nevertheless, they are still considered to be extremely low in credit risk due to their government affiliation, their strong fundamentals, the authority of the Secretary of the Treasury to purchase up to $\$ 2.25$ billion of securities from each, and the belief that the US government would not permit them to fail due both to their size and government affiliation. Ginnie Mae, Fannie Mae, and Freddie Mac are together referred to in this Report as "GSEs."

3. Municipal and state government debt: The sub-sovereign or municipal debt market in the United States has a long history and is very large and diverse. In 2002 , there was approximately $\$ 1.8$ trillion in sub-sovereign debt outstanding in the United States. Approximately $\$ 350$ billion in long-term municipal debt was issued that year, with an additional $\$ 80$ billion in short-term debt issuance. Total issuance of sub-sovereign debt in 2002 thus amounted to $\$ 430$ billion, a $25 \%$ increase over 2001. This increase was due to several factors, including moderate economic growth, the weak stock market which led to a decline in the tax revenues and investment portfolios of municipalities, and the low interest rate environment. Of the total issuance of sub-sovereign debt, about $\$ 120$ billion comprised refinancing and refunding activities, with the remaining being new funds. There are over 50,000 issuers of municipal securities in the United States and 1.5 million different issues. ${ }^{4}$

\footnotetext{
${ }^{2}$ Federal Reserve Bulletin, 1999.

${ }^{3}$ The Bond Market Association calculates the total as \$1,041.5 billion. The figure includes long-term debt issued by Federal Home Loan Bank, Fannie Mae, Freddie Mac, the Student Loan Marketing Association, the Tennessee Valley Authority, and the Federal Farm Credit Bank.

${ }^{4}$ See www.bondmarkets.com, and www.bondtrac.com.
} 
4. Corporate debt securities: Unlike the rest of the fixed income market in the United States, issuance of corporate debt actually declined during 2002 approximately $26 \%$ to $\$ 594.4$ billion. This decline can be attributed to several factors, including investor concerns about corporate credit, the overall reduction in corporate capital raising, and the effect of the corporate and accounting fraud scandals. There appeared to be a slight increase in corporate debt issuance at the beginning of 2003.

Despite the recent decline, however, the US corporate debt securities market remains extremely large, especially when compared with the corporate debt markets in other countries. At the end of 2000, the total market value of outstanding corporate bonds in the United States was approximately \$3.4 trillion. During 2002, $\$ 807$ billion of corporate debt was issued, compared to $\$ 284$ billion of common stock. The US corporate debt securities market is much larger than that of any other country. At the end of 1997 , there was roughly $\$ 5$ trillion of US corporate debt outstanding, making the US market at that time about twice as large as the international debt market for corporate securities and approximately 50 percent larger than the combined corporate debt markets of Japan and the major European countries. ${ }^{5}$

5. Mortgage-related securities: The year 2002 saw approximately $\$ 2.3$ trillion in total issuance of mortgage-related securities, an increase of nearly $40 \%$ from 2001. The majority of this amount, approximately $\$ 2$ trillion, was issued by the GSEs; private issuers were responsible for the remainder. ${ }^{6}$ This substantial increase in the mortgage-backed securities market in 2002 was due in large part to low interest rates, which sparked home sales and mortgage refinancing. It is noteworthy that the market in outstanding mortgage-related securities in 2002 was significantly larger than the outstanding debt of the US government.

6. Asset-backed securities (other than mortgages): Approximately $\$ 485.4$ billion of asset-backed securities were issued in 2002, up 14\% from 2001. The substantial majority of these securities were issued in public offerings. The largest segments of asset-backed securities, other than mortgage-related securities, are those relating to automobile loans, credit card debt, and home equity loans.

7. Money markets: The US money markets consist of a large number of diverse products, including both public and private instruments, that all mature in less than one year. Money market products include US Treasury bills, municipal notes, bank certificates of deposit, commercial paper, federal funds, repurchase agreements, call loans and bankers' acceptances. ${ }^{7}$ As of the end of 2002, the

\footnotetext{
${ }^{5}$ IMF, 1998.

${ }^{6}$ The private label issuers consist largely of commercial banks, savings associations, mortgage companies, and investment banking firms.

${ }^{7}$ Short-term mortgage-related and asset-backed securities (primarily GSE securities) frequently are used for open market operations and for funding purposes to finance broker-dealer businesses, primarily through repurchase agreements or "repos." Repos are secured financing arrangement that allow broker-dealers to finance their activities, bring liquidity to the market and give flexibility to firms. Repos are usually very
} 
outstanding volume of money market instruments totaled approximately $\$ 2.55$ trillion. Individual investors typically own money market securities indirectly through money market mutual funds. As of May 14, 2003, there was a total of $\$ 2.181$ trillion in money market mutual fund assets.

\section{KEY REGULATORS AND THEIR ESPONSIBILITIES}

The US regulatory system is highly fragmented with a number of regulators charged with oversight of the fixed income market. The principal federal ${ }^{8}$ regulators and the key debt market regulatory responsibilities of each are described below.

\section{A. US DePartment OF THE TREASURY}

Article I, Section 8 of the Constitution empowers Congress to borrow funds on account of the US government. Congress delegated this power to the US Department of the Treasury in 1789, giving it responsibility for managing the public revenue and expenditures, and "for the support of public credit." Accordingly, the US Treasury is responsible for, among other things, managing federal finances, collecting taxes and monies paid to the United States, managing government accounts and the public debt; and supervising national banks and thrift institutions. The Treasury Department is responsible for issuing US government securities. Originally, Congress separately authorized each debt issue, but this became tremendously cumbersome. Thus, in 1917 Congress gave Treasury the general authority to borrow funds, subject to the debt ceiling. Treasury's Bureau of the Public Debt ${ }^{10}$ borrows funds under the authority of the Second

short-term, from overnight to 30 days or more. The combination of short-term maturity with government or quasi-government backing means lenders are assuming very low risk.

${ }^{8}$ Because the United States is a federalist system, each State retains the authority to regulate securities that are offered within its borders. Since 1996, however, when Congress adopted the National Securities Markets Improvement Act, significant State securities regulation has been preempted by the federal government. In particular, the Act amended section 18 of the Securities Act of 1933 to preempt state securities regulation from adopting standards that go beyond those required by federal securities law for covered securities and specifically prohibited merit regulation of such securities. State regulation continues to apply to registration of securities sold in that State, requirements for registration of brokerdealers operating in that State, and prohibitions against fraud. Nevertheless, most securities that are exempt from federal regulation are also exempt from State regulation. Also, most States exempt securities that are listed on major stock markets. The 1996 law further prohibited State regulation of certain additional types of securities. Consequently, State regulation is not a major factor in the regulation of the US fixed income market, other than for municipal securities.

${ }^{9}$ Chapter 12, Section 1 of the Act of Congress Establishing the Treasury Department, 1789,"Be it enacted by the Senate and House of Representatives of the United States of America in Congress assembled, That there shall be a Department of Treasury, in which shall be the following officers, namely: a Secretary of the Treasury, to be deemed head of the department; a Comptroller, an Auditor, a Treasurer, a Register, and an Assistant to the Secretary of the Treasury, which assistant shall be appointed by the said Secretary."

${ }^{10}$ The forerunner of the Bureau of Public Debt was created in 1919 by Treasury Secretary Carter Glass. It was designated as a Bureau in 1940 and assumed on behalf of Treasury the rulemaking authority for the government securities market following Congressional adoption of the Government Securities Act of 1986. 
Liberty Bond Act, as amended ${ }^{11}$ subject to the debt ceiling established by Congress. ${ }^{12}$ It manages the public debt by issuing and servicing U.S. Treasury marketable securities, and well as US savings bonds and other special government securities.

\section{B. Federal Reserve SyStem}

The US Federal Reserve System was founded in 1913 by Congress to guarantee the soundness of US banks by ensuring that a capital reserve would be held against all deposits in national banks, and to provide for a safer and more flexible monetary system. The Federal Reserve System consists of the Board of Governors of the Federal Reserve and 12 regional Federal Reserve banks. It is an independent government agency, subject to Congressional oversight. ${ }^{13}$ The Federal Reserve has four main functions: (i) conducting US monetary policy; (ii) supervising and regulating banking institutions; (iii) maintaining the stability of the US financial system; and (iv) providing financial services to the US government, the public, financial institutions, and foreign official institutions. ${ }^{14}$

The Federal Reserve Act of 1913 gave the Federal Reserve responsibility for setting monetary policy. The Federal Reserve implements monetary policy by: (i) conducting open market operations (buying and selling US Treasury securities); (ii) setting discount rates (the rate charged commercial banks and other depositary institutions when they borrow from the Fed); and (iii) establishing reserve requirements for the nation's banks and other depositary institutions. It also acts as the agent for the US Treasury in selling, by auction, new issues of Treasury securities.

The Federal Open Market Committee is composed of the Board of Governors, the president of the Federal Reserve Bank of New York (FRBNY) and four presidents of the other Federal Reserve Banks who serve on a rotating basis. The Open Market Committee oversees the open market operations, the main tool that the Federal Reserve uses to oversee the money and credit supply and to implement monetary policy. ${ }^{15}$ Open market operations are conducted mostly in short-term securities and affect the money supply almost immediately because trades must be settled in three days.

\section{US SECURITIES AND EXCHANGE COMMISSION}

The US Securities and Exchange Commission (SEC) was created by Congress in 1934 as an independent agency in charge of regulating the US securities markets. The SEC's primary mission is to protect investors and maintain the integrity of the securities markets. The SEC also oversees key participants in the securities markets, including stock exchanges, broker-dealers, investment advisors, and mutual funds. As part of its

\footnotetext{
1131 USC Section 3102.

1231 USC Section 3101.

${ }^{13}$ Article I, Section 8 of Constitution gives Congress the power to regulate and control the value of money. It thus oversees the Federal Reserve.

${ }^{14}$ See the Federal Reserve website, www.federalreserve.gov.

${ }^{15}$ By selling Treasury securities, the Federal Reserve reduces the money supply and, conversely, by buying securities, it increases the money supply. Restricting the money supply causes prices to remain stable or go down, and causes interest rates to increase.
} 
responsibility, the SEC requires public companies to disclose material financial and other information to the public, thereby providing information for an investor to use in judging if a company's securities are a good investment. ${ }^{16}$

Crucial to the SEC's effectiveness is its enforcement authority. Each year, the SEC brings between 400-500 civil enforcement actions against individuals and companies for violations of the US federal securities laws. Typical allegations include insider trading, accounting fraud, and providing false or misleading information about the securities that are being offered or sold. The SEC can bring a civil action in US federal district court, seeking an injunction, which is an order that prohibits future violations; a person who violates an injunction is subject to fines or imprisonment for contempt. The SEC also may seek civil monetary penalties and the disgorgement of illegal profits. Such penalties can be substantial, in some cases up to three times the amount of illegal profits obtained. In addition to its civil enforcement authority, the SEC may bring a variety of administrative proceedings, which are heard by administrative law judges and by the SEC Commission itself. Finally, with the passage of the Sarbanes-Oxley legislation of 2002, the SEC may also use administrative proceedings to bar or suspend individuals from acting as corporate officers or directors.

\section{OfFice OF Federal Housing Enterprise OVErsight (OFHEO)}

The Office of Federal Housing Enterprise Oversight (OFHEO) was established as an independent entity within the US Department of Housing and Urban Development in 1992. ${ }^{17}$ OFHEO's primary mission is to ensure the capital adequacy and financial safety and soundness of two GSEs, the Federal National Mortgage Association (Fannie Mae) and the Federal Home Loan Mortgage Corporation (Freddie Mac). ${ }^{18}$ These two entities are the nation's largest housing finance institutions and are responsible for creating a ready supply of mortgage funds for US homebuyers. ${ }^{19}$

OFHEO is responsible for issuing regulations concerning capital adequacy and enforcement standards, conducting oversight examinations and risk-based capital stress tests of Fannie Mae and Freddie Mac, and taking necessary enforcement actions. OFHEO is funded through assessments on Fannie Mae and Freddie Mac.

\footnotetext{
${ }_{17}^{16}$ See SEC website, www.sec.gov.

17 Congress established OFHEO by the Federal Housing Enterprises Financial Safety and Soundness Act of 1992 (Title 13 of P.L. 102-550).

${ }^{18}$ Ginnie Mae is not regulated by OFHEO. It is, itself, a government corporation within the US Department of Housing and Urban Development.

${ }^{19}$ The Federal Housing Finance Board (formerly the Federal Home Loan Bank Board) plays a similar role as OFHEO with respect to the 12 federal home loan banks that were created in 1932 to serve as a central credit system for savings and loan institutions and to help increase the supply of funds to finance home mortgage loans. The Board is an independent federal regulatory agency with a five member board. See www.fhfb.gov.
} 


\section{E. Self-Regulatory Organizations}

The US regulatory system is heavily dependent on the use of self-regulatory organizations or SROs. An SRO is a non-government organization which is legally responsible for regulating its own members through the adoption of rules which it usually has the authority to enforce. ${ }^{20}$ The SEC relies on SRO oversight to assist it in the regulation and day to day surveillance of both the equity and fixed income markets. As noted below, however, the scope of authority of the various SROs is not identical. ${ }^{21}$

1. New York Stock Exchange. The New York Stock Exchange was founded in 1792, initially as a bond-trading exchange. It registered with the SEC as a national securities exchange in 1934, following the passage of the Securities Exchange Act of 1934, and is under the oversight of the SEC. The NYSE is the world's largest auction exchange, with about 2,800 issuers listed, and a total global market capitalization of about $\$ 13.3$ trillion. $^{22}$

The NYSE is a not-for-profit corporation, with a 25 member Board of Directors, comprised of a Chairman, Chief Executive Officer, 12 representatives of the public, and 12 representatives of the securities industry. It is a member organization, and is the lead examining authority for the major securities firms in the United States, including more than 250 member firms that deal with the public, as well as additional brokerage, specialist and registered traders who are members. The NYSE examines firms for their financial condition, operations and sales practices, as well as their compliance with NYSE rules and federal securities laws. The NYSE also conducts real-time surveillance of the market and oversees all trading activities on the Exchange floor.

The NYSE operates a centralized bond market, listing over 2000 corporate, government and agency bonds. The majority of the bonds listed on the NYSE are corporate securities. Listed bonds can trade through the NYSE's Automated Bond System, which maintains and displays prices and matches price orders on a strict price and time priority basis. Both quotes and trades are reported on a real time basis.

2. NASD. The NASD was established under authority granted by Congress in the 1938 Maloney Act Amendments to the Securities Exchange Act of 1934. Like the NYSE, the NASD operates as an independent self-regulatory organization, supervised by the SEC. Virtually every broker-dealer in the United States that

\footnotetext{
${ }^{20}$ The role of SROs in the regulatory system is undergoing significant change in the United States and globally, particularly as exchanges transform themselves from mutual, not-for-profit associations to demutualized, for-profit organizations. Discussion of the implications of these developments for regulation is beyond the scope of this Report.

${ }^{21}$ In addition to the SROs, trade associations can play an important, if not legally enforceable, role in the regulation of the market. The Bond Market Association, for example, is not an SRO but, rather, is a trade association that represents broker-dealers in all aspects of their fixed-income operations. While the BMA has no legal authority to regulate its members, or to take enforcement action against them, it nonetheless plays an extremely effective and important role in the market. See infra.

${ }^{22}$ See NYSE Website, www.nyse.org.
} 
conducts a securities business with the public is required by law to be a member of the NASD. The NASD's membership currently comprises almost 5,400 securities firms that operate more than 92,000 branch offices and employ more than 665,000 registered securities professionals. ${ }^{23}$

The NASD writes rules that govern the conduct of securities firms, examines them for compliance with those rules and with the federal securities laws, and disciplines those who fail to comply. The NASD is responsible for licensing and registration, professional training, investigation and enforcement, and dispute resolution. The NASD monitors all trading on the Nasdaq Stock Market.

On March 15, 2001, Nasdaq submitted an application to the SEC for registration as an exchange. Exchange registration is one step in the disassociation of Nasdaq from the NASD and its transformation into a publiclyowned, for-profit organization. The SEC has yet to act on the Nasdaq application, in part due to the significant implications that such a step would have for market structure and regulation in the United States. As part of the negotiations, the SEC required the NASD to develop an "alternative display facility," which would provide an alternative for electronic communications networks that did not want to post their over-the-counter bids and offers on Nasdaq's SuperMontage network. The ADF was launched on July 25, 2002 for trades in Nasdaq securities.

3. MSRB. Congress established the Municipal Securities Rulemaking Board (MSRB) in 1975 as an independent self-regulatory organization subject to the oversight of the SEC. The MSRB develops rules regulating securities firms and banks involved in underwriting, trading, and selling municipal securities issued by states, cities, and counties or their agencies to help finance public projects. The MSRB is composed of members from both the municipal securities dealer community and the public. The MSRB does not have inspection or enforcement authority. ${ }^{24}$

The large number of federal regulators in the United States means that cooperation and coordination among them is critical to effective oversight. Indeed, following Congressional action to eliminate the remnants of the Glass-Steagall separation of commercial and investment banking, the Federal Reserve and the SEC had to cooperate even more closely in their oversight of complex financial institutions. Ironically, one of the reasons such cooperation has been largely effective in the United States may well be traced to Glass-Steagall itself, and the unusually extensive powers Congress gave to the newly formed SEC in its oversight of investment banks. Because Congress gave the SEC such significant authority, including the ability to bring enforcement actions against - and effectively shut down - banks, the Federal Reserve has to cooperate in a meaningful way with the securities market regulator.

${ }^{23}$ See NASD website, www.nasd.org.

${ }^{24}$ See www.msrb.org. 


\section{DEVELOPMENT AND REGULATORY FRAMEWORK OF THE US FIXED INCOME MARKET}

The development and regulation of the fixed income market in the United States has a long history, one that is very much tied to the development and financing needs of the country itself. The regulation of the fixed income market also is closely tied to the overall development and regulation of the US securities markets, and, in this respect, reflects the US government response to market crises of the past. US federal securities regulation really began in response to the stock market crash of 1929 and the Great Depression. The $1927 \mathrm{McFadden}$ Act, which imposed severe restrictions on the branching activities of banks, the 1933 Securities Act, which mandated disclosure in the securities markets, the 1933 Glass-Steagall Act, which separated commercial and investment banking, and the 1934 Securities Exchange Act, which established the SEC, all laid the foundations for the subsequent development of thriving securities markets. Securities firms, protected from bank competition, developed into powerful financial intermediaries. The SEC, given unusually extensive enforcement powers, became a strong market regulator. Indeed, the first three chairmen of the SEC were all individuals who used their strong personalities and well-established reputations (for good and for ill) to shape the new agency. ${ }^{25}$

The first part of this section briefly outlines the development of the US debt markets, focusing particularly on the development of the market for government securities, GSEs, municipal securities, and corporate debt securities. The broad framework for regulation of the US debt markets is then discussed.

\section{A. Development of US DebT Markets}

1. Government securities. The debt market in the United States, in addition to being substantially larger than the equity market, also significantly predated it. In fact, the New York Stock Exchange actually started in 1792 as an exchange for trading government bonds which had been sold to fund the debt of the American Revolution. ${ }^{26}$ The US government debt market developed, not surprisingly, in tandem with the expansion of the US government. Total government debt remained relatively small until the Civil War, when it increased significantly. It increased again with World War I, and again in the 1930s with the Great Depression and government financing related to World War II. Further increases occurred during the Vietnam War, the subsequent period of high inflation of the 1970s, and government deficit spending in the 1980s. In the second half of the 1990s, total outstanding government debt actually slowed, as the strong US economy and budget surpluses led the US Treasury to decrease its securities issuances and even to initiate a buyback plan. ${ }^{27}$ Since September 11, 2001, the

\footnotetext{
${ }^{25}$ The first three SEC Chairmen were Joseph P. Kennedy, James M. Landis, and William O. Douglas.

${ }^{26}$ Levitt, 1998.

27 The dwindling supply of US Treasury securities caused great consternation among international economists at the time. See, e.g, BIS Papers, 2001.
} 
US Treasury has halted its buyback program, as the weakened US economy, the Bush Administration tax cuts, and significant expenditures relating to the war on terrorism, homeland security and the war in Iraq have increased the spending needs of the US government. ${ }^{28}$

US Treasury securities are direct obligations, and are backed by the full faith and credit, of the US government. Given the sound financial history of the US government, and its ability to generate tax revenues, US Treasury securities are considered to be virtually risk free. Because of their uniquely sound and stable status, US Treasury securities play a key role in debt markets worldwide. They are widely used as a benchmark for pricing other fixed-income securities, ${ }^{29}$ and also are extensively used for investing and hedging purposes. Interest on US Treasury securities is free from state and local taxes, although it is subject to US federal income tax, and the securities themselves are exempt from registration with the SEC. ${ }^{30}$

2. GSEs. Fannie Mae, Freddie Mac and Ginnie Mae were all created by federal law to promote a secondary market for residential mortgage loans and to enhance their liquidity. The existence of the secondary market for mortgage loans enables the originating lenders to sell their loans and use the proceeds to offer new mortgage loans. Fannie Mae was created in 1938 as part of the Federal Housing Administration. In 1968, it was split into two entities, one of which became the investor-owned company that exists today, the other of which, Ginnie Mae, became a wholly owned government corporation. Congress created Freddie Mac in 1970, and it became an investor-owned company in 1989. Fannie Mae and Freddie Mac guarantee payments on their respective securities. Ginnie Mae does not itself issue securities, but guarantees mortgage-backed securities that are issued by qualified mortgage lenders. The common stock of both Fannie Mae and Freddie Mac is listed on the New York Stock Exchange.

The market in mortgage-backed securities began to grow substantially in the 1980s. While the investor base has evolved, it still remains a largely institutional market. Indeed, the GSEs themselves hold more mortgage-backed securities than any other individual investor in the market. Among other things, GSE securities also are widely used for hedging purposes, including hedging "pipeline risk" in the "to-be announced" GSE market. ${ }^{31}$

\footnotetext{
${ }^{28}$ In 1971, Congress set the U.S. Treasury's debt ceiling "permanently" at $\$ 400$ Billion. However, socalled "temporary" increases in the debt ceiling continued. In 1982, actual Treasury debt was three times the "permanent" ceiling, so Congress eliminated the distinction between "temporary" and "permanent" Most recently, Congress raised the debt ceiling from \$6.4 trillion to \$7.4 trillion on May 27, 2003.

${ }^{29} \mathrm{IMF}, 1998$.

${ }^{30}$ Section 3(a)2 of the Securities Act; Section 3(a)(12)Ai of the Exchange Act.

31 "Pipeline risk" is the risk that not all commitments for underlying mortgage loans will close. US SEC, January 2003.
} 
As with US Treasury securities, interest on GSE debt is exempt from state and local tax, and the securities are exempt from registration with the US Securities and Exchange Commission. ${ }^{32}$

3. Municipal securities. The market for municipal securities in the United States has existed for a long time, fostered by its tax exempt status. Traditionally, municipal securities were considered to be a low-risk investment, second in risk only to government securities, and were principally held by institutional investors. Municipal securities also were largely unregulated, due in part to their status as low-risk investments, their institutional investor base, and also, and perhaps primarily, to a combination of Constitutional considerations and political comity preventing the federal government from regulating in an area that belonged primarily to the States. Municipal securities are thus exempt from the registration and reporting requirements of the Securities Act of 1933 and the Securities Exchange Act of 1934. ${ }^{33}$ Unlike US Treasury securities and GSE securities, they also are exempt from federal tax.

In more recent years, however, the perception of credit risk in the municipal securities market has grown for several reasons, including, primarily, the financial crisis of several major municipalities, such as the New York City financial crisis of 1975, the Washington Public Power Supply bond defaults in 1983, and the more recent crisis in Orange County, California in 1994. Other factors that contributed to the perception of increased credit risk in the municipal securities marked included the amendment in October 1979 to the federal bankruptcy law, which made it easier for municipal issuers to file for bankruptcy, the proliferation of new and creative financing techniques with legally untested structures, and the more recent cutbacks on federal aid to municipalities and overall changes in US economy that could harm the financial health of municipalities. Consequently, beginning with the Securities Acts Amendments of 1975, Congress has brought dealers in municipal securities within the reporting framework of the Securities Exchange Act of 1934. The Securities Acts Amendments also required the SEC to establish an independent self-regulatory organization, the Municipal Securities Rulemaking Board (MSRB), to help regulate the municipal securities market under the oversight of the SEC.

4. Corporate debt securities. As US corporations formed, the market for issuance of corporate debt securities also developed. Between 1850 and the early 1900s, public utilities and manufacturing corporations began issuing corporate bonds as a financing vehicle. By far the dominant market player, however, were railroad corporations, which issued debt to finance their expansion across the United

\footnotetext{
${ }^{32}$ Ginnie Mae does not itself issue securities, but guarantees mortgage-backed securities that are issued by qualified mortgage lenders. Because it is a wholly-owned US government corporation, the securities that it guarantees are exempt under Section 3(a)(2) of the Securities Act and Section 3(a)(12) of the Exchange Act. The securities of Fannie Mae and Freddie Mac are expressly exempted from SEC registration by the enabling statutes, the Federal National Mortgage Association Charter Act, 12 USC section 1723(c), and the Federal Home Loan Mortgage Corporation Act, 12 USC section 1455(g).

${ }^{33}$ Section 3(a)(2) of the Securities Act; Section 3(a)(12)Aii of the Exchange Act.
} 
States. Between 1900 and 1917, the amount of outstanding US corporate debt tripled, from $\$ 6$ billion to more than $\$ 19$ billion, thus exceeding the US government debt. ${ }^{34}$

The US corporate debt market is much older than that of most other countries. In 1880, there were approximately $\$ 2$ billion outstanding in US corporate debt securities issued by non-financial corporations (about $16 \%$ of GNP). Corporate bond markets in most other countries were still virtually nonexistent in 1980, one hundred years later. ${ }^{35}$ Another striking difference between the US corporate debt securities market and that of other markets is the extent to which it is broadly diversified. Indeed, corporate debt historically has been a source of financing for a diverse cross-section of US businesses. ${ }^{36}$ The market is substantially less dominated by financial institution issuers than that of other countries. For most of its long history, the corporate debt market was a slowmoving market. Corporate bonds, which were originally sold literally door-todoor, were investments that were largely bought to be held. In the 1970 s, however, the nature of the market began to change. The inflation of the mid1970 s, the deficit spending of the 1980s, and technological advances of the 1990s all caused significant changes in the US corporate debt market, transforming it into a large global market that plays a significant role in the US economy.

\section{B. Framework For REgulation OF US DEbT MARKeTS}

1. Legal and regulatory infrastructure. Regulation does not exist in a vacuum. Fundamental to the shape of regulation and to its effectiveness is the infrastructure that supports it. ${ }^{37}$ In the United States, the regulation of the fixed income market, and the different segments of that market, is determined by the US legal structure, the commercial and tax codes, US financial and regulatory history, and US business traditions and culture. Also relevant to the development of a large investor base with confidence in its ability to evaluate credit and market risk are US accounting standards (US GAAP) and US corporate law. ${ }^{38}$

This section of the Report will describe the fundamental framework for regulation of securities offerings in the United States. The next section will then describe the specific regulatory regimes for different types of securities offerings.

2. Registration as basis for regulation-primary market. Regulation of the offering of fixed income instruments in the United States depends largely on the nature of

\footnotetext{
${ }^{34}$ Levitt, 1998.

${ }^{35}$ IMF, 1998.

${ }^{36}$ In the United States, there are five main categories of issuers of corporate bonds: (i) public utilities; (ii) transportation companies; (iii) industrial corporations; (iv) banks and other financial services companies; and (v) conglomerates or international issuers.

${ }^{37} \mathrm{See}$, IOSCO, 1998.

${ }^{38}$ In the United States, there is no federal company law. All corporate laws are state-based. The relationship between the federal and state governments, and the Constitutional implications of federal regulation, are particularly evident in the development of regulation of the municipal securities market.
} 
the issuer and the type of product that it offers. As described in detail in Section IV below, if the issuer is required to register its product under the Securities Act of 1933 (the Securities Act), then offerings of that product will be subject to the regulation promulgated by the SEC pursuant to that Act. If, on the other hand, the security is exempt from the Securities Act, then offerings will either be exempt from regulation altogether, or subject to a different regulatory scheme.

The Securities Act is premised on the theory of disclosure. The concept is that an issuer should disclose to investors all material information, that is, information that there is a substantial likelihood that a reasonable investor would consider important in deciding whether to make the investment. ${ }^{39}$ Investors are not given any guidance as to the merits of a particular issuer or security, and the decision as to whether a specific investment is left to them. However, because they are required to disclose material information, issuers are more likely to comply with all applicable laws and regulations. Thus, a disclosure-based system is often described in shorthand as working because "sunshine makes the best disinfectant." A similar notion is expressed in another common aphorism, "[t]hose who must undress in public are likely to pay closer attention to their figures."

The heart of the Securities Act is its basic registration requirement which is set forth in Section 5. Pursuant to Section 5, all securities that are offered or sold to the public must be registered with the SEC, unless they are expressly exempted from registration by the terms of the Act. ${ }^{40}$ This registration requirement applies to debt securities to the same extent that it applies to equity securities. Once subject to the registration requirement of the Securities Act, offerings of debt securities are then subject to the Act's disclosure requirements.

The Securities Act does, however, contain a number of exemptions from the registration requirement. In some cases, it is a particular type of security which is exempt from registration, in part due to the nature of the issuer; in other cases, it is the type of transaction that is exempt.

a) Exempt Securities. There are a number of securities that are exempt from the registration requirement of Section 5. These include US government securities, which are exempt because they are backed by the US government, ${ }^{41}$ the securities of Fannie Mae and Freddie Mac, which are exempt because of the express provisions of their Congressional charters, ${ }^{42}$ the securities of domestic banks or trust companies, which are subject to the approval of the bank supervisors,

\footnotetext{
39 TSC Industries, Inc. v. Northway, Inc., 426 US 438 (1976).

${ }^{40}$ Securities Act, Section 5.

${ }^{41}$ Securities Act, Section 3(a)(2), 15 USC section 77c(a)(2). This exemption applies also to the securities that are guaranteed by Ginnie Mae. Note, however, that debt securities offered in the United States by other sovereigns must be registered with the SEC under Schedule B of the 1933 Act.

${ }^{42}$ The Federal National Mortgage Association Charter Act, 12 USC section 1723(c); The Federal Home Loan Mortgage Corporation Act, 12 USC section 1455(g).
} 
securities issued by international financial institutions, commercial paper, which is an investment-grade security that matures in less than one year, and debt securities that are used substantially as commercial instruments and are not issued primarily for an investment purpose (such as, for example, bank certificates of deposit). ${ }^{43}$ In addition, municipal debt securities are exempt from registration under the Securities Act, although, as discussed later, they are subject to the antifraud provisions of the securities laws and to other forms of regulation.

b) Exempt Transactions. In addition to exempt securities, the Securities Act also confers registration exemptions on certain types of transactions. Most significantly, exempt transactions include "private placements," which are securities offered to a limited number of purchasers. Exempt transactions also include securities offered only to "sophisticated" or "accredited" investors. ${ }^{44}$ Registration is considered unnecessary because the purchasers generally are considered to have the size and sophistication, and market leverage and access, to protect themselves. Under Regulation D of the Securities Act, an issuer can offer an unlimited amount of securities to "accredited investors" without registration and therefore without supplying any specific information, as long as no general solicitation or general advertising takes place. ${ }^{45}$ A private placement ${ }^{46}$ generally consists of the offering of large blocks of securities to "accredited" institutional investors, and is frequently used by companies as a way of placing their debt securities.

\section{SPECIFIC REGULATORY REGIMES}

This section of the Report describes the US regulatory requirements for the public offering of different types of fixed-income securities. As indicated above, government securities are exempt from the registration requirements of the Securities Act. This is true, as well, for the securities of GSEs and for municipal securities. As can be seen

\footnotetext{
${ }^{43}$ See, e.g., Securities Act, Section 4.

${ }^{44}$ The US securities laws use different terms in different sections to indicate an investor with a sufficient level of sophistication in its investment dealings so as not to need the protections of the full US securities regulatory regime. An investor's level of income or wealth is used as a rough indicator of such sophistication. The terms "sophisticated," "accredited," and "institutional" are used in different sections of the securities regulations and they each have slightly different definitions.

${ }^{45}$ According to James M. Landis, one of the original drafters of the Securities Act and the second chairman of the SEC, sophisticated or institutional investors were not the focus of concern. He wrote, "[t]he sale of an issue of securities to insurance companies or to a limited group of experienced investors, was certainly not a matter of concern to the federal government. That bureaucracy, untrained in these matters as it was, could hardly equal these investors for sophistication, provided only it was their own money that they were spending. James M. Landis, 1997.

${ }^{46}$ Securities Act, Section 4(2). See also Regulation D.
} 
below, however, the offer and sale of these securities is not exempt from all regulation. Corporate debt securities are not exempt from registration, and, with some differences that are highlighted below, are subject to the disclosure requirements of the Securities Act to the same extent as equity securities.

\section{A. GovernMent SeCURities}

As noted above, US government securities are exempt securities under the Securities Act and therefore are not subject to the Act's registration requirements. They also are exempt from the registration requirements of the Securities Exchange Act of 1934 (the Exchange Act). ${ }^{47}$ However, government securities are not entirely exempt from regulation. In 1986, Congress passed the Government Securities Act (GSA) to "protect investors and ensure the maintenance of a fair, honest and liquid market." GSA for the first time established a comprehensive legal framework regulating all government securities brokers and dealers. The legislation focuses on the capitalization of broker-dealers and grants to the US Treasury the authority to develop and implement rules regarding transactions in government securities. For previously regulated entities, examination and enforcement of these rules is delegated to the existing regulatory agencies and self-regulatory organizations with which the entity had an existing regulatory relationship. As a practical matter, this means that, while Treasury is responsible for developing the applicable rules, which it has done in consultation with both the SEC and the Federal Reserve, the securities regulators and banking supervisors remain responsible for inspection and enforcement to ensure that firms engaged in government securities transactions are in compliance with those rules.

Prior to the enactment of the GSA, firms that conducted transactions solely in government securities were not required to register with the SEC. In 1985, there were approximately 200-300 firms that were not subject to any form of regulation whatsoever. ${ }^{49}$ As the government securities market grew in the early 1980 s, however, with the growth in deficit spending, government securities dealers developed a number of problems. Moreover, the market's rapid growth came at a time of falling interest rates, thus increasing investors' demand for higher yield and their laxity in investment practices. These factors together led to the failure of two government securities dealers in 1985, ESM Securities and Bevill, Bresler \& Schulman. The failure of ESM Securities was particularly significant because it in turn led to other failures, including, notably, the failure of the Home State Savings Bank in Ohio. The Bank's failure caused the insolvency of Ohio's state-chartered savings banks' mutual deposit guarantee fund. The result was Congressional hearings and Congressional adoption of a regulatory scheme for government securities dealers. ${ }^{50}$

\footnotetext{
${ }^{47}$ Government securities are exempt securities under Section 3(a)(2) of the Securities Act and Section 3(a)(12) of the Exchange Act, 15 USC section 77c(a)(2), 15 USC section 78c(a)(12).

${ }^{48}$ Pub. L. No. 99-571, 100 Stat. 3208.

${ }^{49}$ Burnham, 1990.

${ }^{50}$ See Burnham, id., for a more detailed analysis of the confluence of business, political and regulatory interests which produced the Government Securities Act of 1986 and the designation of the US Treasury Department as the primary regulator of government securities dealers.
} 
The GSA added Section $15 \mathrm{C}$ to the Exchange Act. Section $15 \mathrm{C}$ requires brokerdealers who limit their activity to government securities to register as government securities broker-dealers, provided that they are not banks or other "financial institutions." Financial institutions that deal in government securities must file a notice with the "appropriate regulatory agency" (their federal regulator). General purpose broker-dealers that conduct a government securities business also must file a notice with the SEC regarding this activity. All firms that conduct a government securities business must comply with rules adopted by the Secretary of the Treasury, as well as with SEC, NASD, or bank supervisory, rules. As noted above, inspection and enforcement functions are carried out by the securities regulators and banking supervisors, as applicable. Approximately 2000 securities broker-dealers are registered with the SEC to operate in the government securities market, as required by the GSA.

In 1993, Congress enacted additional legislation relating to the government securities market, again in response to a scandal. The Government Securities Act Amendments (GSAA) were prompted by evidence that Salomon Brothers had "cornered" or manipulated the market in certain government securities. ${ }^{51}$ Among other things, the GSAA gave the Treasury Department the authority to prescribe large position recordkeeping and reporting rules, and authorized the bank regulatory agencies, including the Federal Reserve Board, and the NASD to develop sales practice rules for the government securities market. ${ }^{52}$

Marketable Treasury securities are issued in the primary market via regularly scheduled auctions. Participation in auctions is not restricted to registered dealers. Indeed, auction bids are submitted by a large and diverse group of individuals and entities. In 2002, Treasury auctioned a total of $\$ 3.8$ trillion securities, of which $\$ 2.5$ trillion were sold to primary dealers. ${ }^{53}$ Primary dealers are either commercial banking organizations that are subject to official supervision by federal bank supervisors, or are broker-dealers that are registered with the SEC. They serve as principal market makers, buying and selling from customers for their own accounts at quoted bid and asked prices and are required to file regular trading and position reports with the FRBNY.$^{54}$ They also have access to real-time, screen-based information and trading systems provided by inter-dealer brokers. There are currently 22 primary dealers. ${ }^{55}$ These firms are selected by the FRBNY as counterparties for open market operations. Primary dealers are not regulated as such by the FRBNY; rather, they have a business relationship with the FRBNY, and, as part of that relationship, must participate meaningfully in open market operations and Treasury auctions and supply information about market conditions to the FRBNY.

Commercial auction bids, i.e., bids on behalf of commercial entities, generally are entered through the Treasury Automated Auction Processing System (TAAPS), an

\footnotetext{
${ }^{51}$ A more detailed description of these events is contained infra, at pages 40-41.

${ }^{52}$ US SEC, March 1998.

${ }^{53}$ Remarks to the Bond Market Association, Deputy Assistant Secretary of the Treasury Timothy Bitsberger, April 2003, www.ustreas.gov/press/releases.

${ }^{54}$ Federal Reserve Board of New York, Fedpoint2.

${ }^{55}$ As of October 2003. Id.
} 
automated system that was implemented in the early 1990s. Most bids, however, are entered through TreasuryDirect, a system which permits retail investors, subject to certain conditions, to buy Treasury Securities directly from the US government. ${ }^{56}$ Bids can either be competitive bids, which specify both the quantity and yield of the security sought, or non-competitive, in which the bidder agrees to accept the yield determined at the auction and in return is guaranteed the amount of security sought. Most TreasuryDirect bids are non-competitive bids. ${ }^{57}$ Nevertheless, a majority of the total dollar value that is bid overall is bid competitively. Since November 1998, all Treasury securities have been auctioned at a uniform price, meaning all successful bidders are awarded securities at the same price, which is equal to the highest rate or yield of the competitive bids that are accepted, also known as the "stop-out" yield. ${ }^{58}$

The US Treasury announces the tentative auction calendar in advance on a quarterly basis. It also announces each auction in advance. The announcement includes details of the planned offering, such as the amount, term, and type of securities that will be offered. After the auction is announced, but before it actually occurs, trading begins in the security that is intended to be offered, creating a "when-issued" market in government securities. The when-issued market facilitates the efficient distribution of government securities to investors and provides useful price information to bidders ahead of the auction. The FRBNY coordinates the auction activity.

\section{B. GSES}

The securities issued by the GSEs ${ }^{59}$ are exempt from registration under both the Securities Act and the Exchange Act of 1934, and are effectively treated as government securities under the US federal securities laws. ${ }^{60}$ Ginnie Mae is wholly-owned by the US government and its guarantees are backed by the full faith and credit of the US government. While Fannie Mae and Freddie Mac's obligations are not federally guaranteed, they are still treated as government securities under the securities laws because of express provisions in their Congressional charters. As exempt securities, GSE securities may be offered and sold without registration. As "government securities," they may be traded by government securities broker-dealers.

\footnotetext{
${ }^{56}$ While bids still can be mailed to several Federal Reserve banks, the majority of bids are no longer made this way.

${ }^{57}$ See www.publicdebt.treas.gov.

${ }^{58}$ Federal Reserve Bulletin, 1999, supra note 2, at 788. "Since November 1998, all Treasury securities have been auctioned according to the uniform-price method." See, also, www.publicdebt.treas.gov.

"Treasury bills, notes, and bonds are sold at single-price auctions." In a single-price auction, all successful competitive bidders and all noncompetitive bidders are awarded securities at the price equivalent to the highest accepted rate or yield of accepted competitive tenders. A complete explanation of the auction process is contained in the Uniform Offering Circular, 31 CFR Part 356.

${ }^{59}$ Ginnie Mae does not issue mortgage-backed securities; rather, it guarantees payment on mortgagebacked securities that are backed by federally insured or guaranteed loans, such as loans insured by the Federal Housing Authority or loans guaranteed by the Department of Veterans Affairs. Fannie Mae and Freddie Mac both issue and guarantee mortgage-backed securities.

${ }^{60}$ GSE securities are also exempt from the Trust Indenture Act of 1939, and the Investment Company Act of 1940 .
} 
The primary market in GSEs consists both of sales to dealers and direct sales to investors. Most commonly, new GSE securities are allocated among members of a selling group of dealers. The selling group provides both market and trading information to the issuer and may support secondary trading.

Because their securities are exempt from registration, the GSEs have not historically filed any offering materials with the SEC. They do, however, prepare offering documents that are similar to the offering documents of private corporations. They also make extensive information available to investors through their websites. For example, they all provide full audited financial statements. ${ }^{61}$ Investors receive additional information as part of their confirmation of a "to-be-announced" trade, in accordance with the Good Delivery Guidelines of the Bond Market Association. ${ }^{62}$ The Good Delivery Guidelines represent standard industry practice for trading and settling mortgage-backed securities in the to-be-announced market. ${ }^{63}$ These materials are all subject to the antifraud provisions of the US securities laws which apply, even though GSE securities are exempt from registration.

Since Ginnie Mae's securities are guaranteed by the US government, disclosure during primary market offerings has never been a controversial issue. In contrast, Fannie Mae and Freddie Mac were caught up in the corporate disclosure reform that swept the United States in 2002. As a result, the two GSEs make an extensive amount of information available to the public. Investors considering a purchase of GSE securities can also obtain information from OFHEO about the creditworthiness of the GSEs themselves, including results of examinations and risk-based capital stress tests. ${ }^{64}$

\section{Municipal Securities}

Like government securities and the securities of GSEs, municipal securities are also exempt from registration under the Securities Act and the Exchange Act. ${ }^{65}$ Offerings of municipal securities thus do not have to comply with the disclosure requirements of the federal securities laws. They are, however, subject to the antifraud provisions. A substantial number of municipal securities is brought to market each week. They may be offered via a registered public offering or a private placement, and are sold through both

\footnotetext{
${ }^{61}$ Under the Chief Financial Officers Act of 1990, Ginnie Mae is required to report annually to Congress on its financial condition. As part of this requirement, Ginnie Mae prepares audited financial statements. Fannie Mae and Freddie Mac also prepare annual audited financial statements, which they presumably are required to do in any case as listed companies.

${ }^{62}$ See The Bond Market Association, 1990.

${ }^{63}$ The Good Delivery Guidelines set forth the basic features that a mortgage-backed security must have to be eligible to be sold in the TBA market. The Good Delivery Guidelines were developed to provide liquidity and fungability in a market that is highly differentiated and in which the sales of the security occur before the underlying mortgage loans have closed.

${ }^{64}$ See more detailed discussion, infra, page 31.

${ }^{65}$ Securities Act, Section 3(a)(2), 15 USC Section 77c (2001); Exchange Act, Section 3(a)(12), 15 USC Section 78c (2001).
} 
auction and negotiated sales. Increasingly, new issues of municipal securities are sold over the Internet. ${ }^{66}$

US regulation of municipal securities really began in the 1970s. Following the financial crisis in New York City in 1975, Congress amended the Securities Act to add Section 15B, thereby bringing municipal dealers within the Act's reporting requirements. ${ }^{67}$ Congress also mandated at that time that the SEC establish the Municipal Securities Rulemaking Board (MSRB) as an independent self-regulatory organization under the oversight of the SEC to develop rules governing municipal securities dealers. The MSRB issues rules regulating the municipal securities activities of both banks and securities firms. All MSRB rules must be approved by the SEC and violation thereof is a violation of federal law under the Exchange Act. ${ }^{68}$ Inspection and enforcement authority remain with the NASD and the SEC (or, for dealer banks, the FRBNY or their normal regulatory authority).

The evolution of the municipal securities market from an institutional market to one in which a large portion of investors were individual investors, either directly or through mutual funds, resulted in continued pressure to increase disclosure. ${ }^{69}$ The spectacular \$2 billion default by the Washington Public Power Supply System in 1983, after a public offering in which it had raised funds to build two nuclear power plants, precipitated a series of Congressional hearings, and motivated the SEC to adopt Rule $15 \mathrm{c} 2-12$, the first bond disclosure rule, in 1989. Rule 15c2-12 requires underwriters participating in primary offerings of municipal securities of $\$ 1,000,000$ or more, to obtain a disclosure document, typically called an "Official Statement," within seven business days after any final agreement to purchase, offer, or sell an issuer's municipal securities. The SEC also approved an MSRB rule requiring the mandatory filing (although not review) of Official Statements with the MSRB. ${ }^{70}$ Such Statements must be distributed to investors at the time the underwriter sends out the confirmations. They are thus easily accessed by the public. ${ }^{71}$ This somewhat unusual form of disclosure regulation, where the requirement is imposed on the underwriter rather than the issuer, results from the exemptions given to municipal securities under the federal securities laws.

The Official Statement is intended to provide full disclosure to the purchaser and it is subject to the antifraud provisions of the securities laws. Thus, the Statement must not include any untrue statement of a material fact, or fail to state a material fact necessary in order to make the statements made, in light of the circumstances in which

\footnotetext{
${ }^{66}$ Maco, 2001.

${ }^{67}$ Pub.L.No. 94-29, s9 Stat. 131 (1975).

${ }^{68}$ Exchange Act, Section 15B(c)(1), 15 USC Section 78o-4 (2001).

${ }^{69}$ In 2000 , it was estimated that $73 \%$ of the municipal bonds outstanding in the United States were held by individual investors, either directly or through mutual funds. Martha Mahan Haines, 2000. Pension funds do not hold a significant percentage of municipal bonds in the United States, primarily because they do not need to take advantage of their tax-exempt status.

70 MSRB Rule G-36, Rule Approval Notice, 55 Fed. Reg. 23333 (1990). Official Statements are not filed with the SEC.

71 MSRB Rule G-32.
} 
they were made, not misleading. Through the antifraud provisions, the issuer has ultimate responsibility for its offering statements. ${ }^{72}$

The SEC has brought numerous enforcement actions against municipal issuers for failing to make full disclosure in their Official Statements. ${ }^{73}$ Most recently, in March 2003, the SEC issued a cease and desist order against the City of Miami, for making material misstatements and omissions in its Official Statements in connection with three bond offerings. In the course of raising funds, Miami had failed to disclose its dire financial straits and, in particular, had omitted to state that the city was experiencing a severe cash flow crisis and, consequently, might not be able to meet its operating expenses. The SEC also held that Miami had violated the antifraud provisions of the securities laws in connection with its annual financial report and related transmittal letter because it mischaracterized the city's financial condition by painting a materially false, optimistic picture.

\section{CORPORATE DEBT SECURITIES}

Unlike government securities, the securities of GSEs, or municipal debt securities, corporate debt securities are subject to the registration and reporting provisions of the Securities Act and the Exchange Act. To a great extent therefore, regulation of the initial offering of debt securities is similar - even identical - to the regulation of equity offerings.

1. General requirements. The Securities Act makes it illegal to offer or sell to the public securities that are not otherwise exempt unless they have been registered with the SEC. ${ }^{74}$ The purpose is to ensure that the public has access to sufficient and reliable information about the securities that are being offered. An issuer registers its securities by filing a registration statement with SEC containing information and documents about the issuer and the securities that are being offered. This registration statement is the same, whether it is for fixed-income securities or for equity securities. ${ }^{75}$ The registration statement has two parts: the prospectus, which is the document by which the offer is made and which must be delivered to each purchaser, and supplementary information, which is filed with the SEC and available to the public, but does not have to be delivered to the purchaser. A key element of the prospectus is the "management discussion and analysis" (MD\&A). ${ }^{76}$ This section is supposed to provide, in "plain English,"

\footnotetext{
${ }^{72}$ See, e.g., County of Orange, California, Exchange Act Rel. No. 36761 (Jan. 24, 1996), 61 SEC Docket 487 (public issuers are primarily liable for the content of their disclosure documents and are subject to proscriptions under the antifraud provisions).

${ }_{73}^{73}$ Many of these cases are posted on the SEC's website, www.sec.gov.

${ }^{74}$ While the Securities Act does not define a "public" offering, transactions that are exemption from registration under the Act include "non-public" offerings, which are those offerings or private placements in which there is no public advertising, seminars or general solicitation. Instead, there can be discreet approaches to a relatively small number of generally "accredited" or "sophisticated" investors.

75 The SEC currently is engaged in a project to develop specialized disclosure forms for the offering of asset-backed securities. See Beller, 2003.

${ }^{76}$ Required pursuant to Item 303 of Regulation S-K.

${ }^{77}$ Amendment to Rule 421 under the 1933 Act, SEC Rel. 33-7380, 1997.
} 
view of the company through the eyes of management. Many of the SEC's new disclosure rules that were issued following adoption by Congress of the SarbanesOxley Act in 2002 focused on enhancements to MD\&A. ${ }^{78}$ If an issuer omits or misrepresents any material fact in the registration statement, investors may file an action in US federal court to recover part or all of their investment from the issuer, the underwriter or both. Investors also can file an action against the chief executive officer, the chief financial officer, the chief accountant, each of whom must sign the registration statement, each of the directors, a majority of whom must sign the registration statement, and the independent accountants as experts with regard to the issuer's audited financial statements.

An issuer may not offer or sell the security prior to the filing of the registration statement. ${ }^{79}$ While the registration statement technically would automatically become "effective" 20 days after it is filed, there is an routine delaying amendment that prevents the 20 days from running while the SEC is undertaking its review. When the SEC review has been completed, a request for acceleration is granted, at which point the public offering can commence. ${ }^{80}$ During the waiting period, while offers can be made, any written statement generally has to comply with the "prospectus requirement." This means that the issuer generally may not transmit any material relating to the security, other than the required prospectus. An issuer may, however, prepare and deliver a "preliminary prospectus," which essentially contains all the information in the final prospectus, other than the pricing information. ${ }^{81}$ An issuer can request that the effective date of the registration statement be accelerated if it agrees to deliver a preliminary prospectus at least 48 hours prior to the effective date. The final prospectus must be delivered to the purchaser along with the purchase confirmation at the latest. The SEC also has permitted underwriters of mortgagebacked and asset-backed securities to distribute written "computational materials" and structural and collateral term sheets to investors prior to the availability of a final prospectus. ${ }^{82}$

In permitting a registration statement to become effective, the SEC is essentially indicating that it has no reason to believe that the prospectus contains incomplete or inaccurate information. The SEC has not approved the security or the offering, and any representation to the contrary is a criminal offense.

2. Special requirements for offers of corporate debt securities. In addition to the requirements of the Securities Act, a corporation that wishes to make a public

\footnotetext{
${ }^{78}$ See e.g., SEC proposals relating to identification of critical accounting policies, Securities Act Rel. 338098, Exchange Act Rel. 34-45907, and disclosure of off-balance sheet arrangements and aggregate contractual obligations, Securities Act Rel. 33-8182; Exchange Act Rel. 34-47264.

${ }^{79}$ Securities Act, Section 5(c).

${ }^{80}$ Section 8(a) of the 1933 Act.

${ }^{81}$ Tombstone ads are also permissible. Securities Act, Rule 134.

${ }^{82}$ Greenwood Trust Company, Discover Card Master Trust II, SEC No-Action letter (April 5, 1996), Kidder, Peabody Acceptance Corporation I, SEC No-Action Letter (May 20, 1994), and Public Securities Association, SEC No-Action Letter (May 27, 1994).
} 
offering of debt securities also must comply with the requirements of the Trust Indenture Act of 1939. The Trust Indenture Act applies to corporate issuers of debt securities in a principal amount of $\$ 10$ million or more. Pursuant to the Trust Indenture Act, a corporate issuer of debt securities must prepare an indenture, or debt instrument, that sets forth the rights and obligations of the bondholder, the issuer, and the corporate trustee who has been appointed to carry out the terms of the indenture. Along with the Securities Act registration statement, the issuer must file an indenture qualification statement registering the indenture with the SEC.

The Trust Indenture Act requires that a trustee be appointed to protect the interests of corporate bondholders, and establishes the standards of eligibility and qualification. It also establishes the trustee's minimum rights, powers, and duties, and requires than the indenture include particular provisions for the benefit of the bondholders. The Act also requires fair disclosure to the securities holders of key provisions of the indenture. Upon default, the legal claims of corporate bondholders have priority as creditors over common and preferred shareholders.

Issuers of corporate debt securities frequently also take advantage of the shelf registration provisions of Rule 415 promulgated under the Securities Act. ${ }^{83}$ Rule 415 permits issuers that are Exchange Act reporting companies, under certain circumstances, to register an offering of securities with the SEC and then "put it on the shelf," available to draw down at different times and upon short notice when market conditions are favorable. Shelf registration can be useful for issuers of debt instruments in lieu of, for example, medium-term bank loans as it permits issuers to respond rapidly to take advantage of a decline in interest rates.

3. Private placements. Many corporate debt securities that are offered and sold in the United States are not public offerings and therefore do not comply with the registration and reporting requirements of the Securities Act. Instead, many corporations choose to offer their securities by making a private placement in accordance with the provisions of the Securities Act. Issuers who are smaller, less well-known companies or who have complex financing structures may have limited access to the public market which services larger companies with credit risks that can be more easily evaluated on the basis of public information. Such smaller issuers can, instead, can take advantage of the private placement market. ${ }^{84}$

Section 4(2) of the Securities Act exempts transactions that do not involve a public offering of securities. In 1982, pursuant to Section 4(2), the SEC adopted Rule 506 as part of Regulation D. Rule 506 provides a non-exclusive safe harbor $^{85}$ under which an issuer can make an offering that will not be considered to be a public offering under the Securities Act. An issuer that complies with Rule

\footnotetext{
${ }^{83}$ Securities Act, Rule 415, Delayed or Continuous Offering and Sale of Securities.

${ }^{84}$ Carey, 1993.

${ }^{85}$ A "non-exclusive safe harbor" means that, while Rule 506 is not the sole means to make a Section 4(2) private placement, if an issuer follows all of the provisions of Rule 506, it can be "safe" or assured that the registration exemption will apply.
} 
506 can be certain that it is conducting an offering that is properly exempt as a "private offering" under Section 4(2). Under Rule 506, an issuer may offer and sell securities to an unlimited number of "accredited investors" 86 and a limited number of non-accredited investors without registration. All non-accredited investors must, however, meet certain conditions of "sophistication." According to Rule 506, each non-accredited investor must "either alone or with his purchaser representative(s) [have] such knowledge and experience in financial and business matters that he is capable of evaluating the merits and risks of the prospective investment, or the issuer reasonably believes immediately prior to making any sale" that the investors fits that description. Any offering under Rule 506 to nonaccredited investors requires delivery of specified information to those investors.

In general, securities that are acquired in a private placement are "restricted" securities and cannot be resold unless registered with the SEC or subject to an exemption. In 1990, the SEC adopted Rule 144A, providing a nonexclusive safe-harbor from the registration requirements of the Securities Act for resales of restricted securities to "qualified institutional buyers" or QIBs. ${ }^{87}$ The SEC's purpose in adopting Rule 144A was to increase the liquidity of privately placed securities and to increase access to the market for non-US issuers. By providing an exemption from registration, the SEC was able to attract many nonUS issuers who were eager to tap US capital pools but reluctant to submit themselves to the requirements of registration and disclosure, including the necessity of preparing financial statements in accordance with, or reconciled to, US GAAP. ${ }^{88}$ Studies of the Rule 144A market suggest that Rule 144A has in fact worked as intended and that "the majority of foreign issuers now opt to raise debt in the 144A market rather than the public debt market, more so if they are issuing high yield or non-rated debt." 89

Following the adoption of Rule 144A, the NASD created the PORTAL (Private Offerings, Resales and Trading through Automated Linkages) trading system, which further increased the liquidity of the market. PORTAL is a screenbased system designed to facilitate the trading of Rule 144A securities by QIBs. Together, Rule 144A and PORTAL have substantially expanded the market for corporate debt securities in the United States. Issuers relying on Rule 144A may also avoid compliance with SEC requirements concerning disclosure, accounting,

\footnotetext{
${ }^{86}$ Rule 501 of Regulation D defines "accredited investor" to include, among others, certain institutions, organizations, and entities, as well as a natural person whose individual net worth, or joint net worth with that person's spouse, at the time of his purchase exceeds $\$ 1$ million, and any natural person who had an individual income in excess of $\$ 200,000$ in each of the two most recent years or joint income with that person's spouse in excess of $\$ 300,000$ in each of those years and has a reasonable expectation of reaching the same income level in the current year. Securities Act, Rule 501.

${ }^{87}$ A QIB generally includes institutional investors that own and invest on a discretionary basis at least $\$ 100$ million in securities of issuers unaffiliated with the QIBs or \$10 million in the case of broker-dealers. QIBs also include US banks and savings and loan associations. Securities Act, Rule 144A (17 CFR 230.144A).

${ }^{88}$ Of course, US investors, particularly institutional investors, may demand US GAAP financial statements even if they are not technically required under Section 4(2) and Rule 144A.

${ }^{89}$ See, e.g., Chaplinsky, 2000.
} 
and ongoing periodic reporting requirements of the 1934 Act. Rule 144A does, however, contain a moderate information disclosure requirement that applies if the issuer is not otherwise an Exchange Act reporting entity. Generally, such issuers are required to provide a brief statement of their business, products and services, and financial statements for the preceding two years. While the financial statements must be audited "to the extent possible," a full US GAAP reconciliation is not required. However, foreign private issuers may comply instead with Rule 12g3-2(b) of the Exchange Act under which they only have to provide the SEC whatever information the issuer has made or is required to make public in its home country. ${ }^{90}$ The information may be provided in the language of the home country, except for shareholder communications and press releases which must be in English. However, the antifraud provisions of the securities laws are applicable to all disclosures that are made by issuers. ${ }^{91}$ Thus, for liability purposes, information given to purchasers in a private placement/Rule 144A transaction is substantially comparable to that contained in a prospectus in a registered public offering. The extent of liability for information in "home country reports" that are provided to the SEC is not clear.

\section{SECONDARY MARKET TRADING}

US government securities and the securities of GSEs both enjoy an active and liquid secondary market. The secondary market in municipal securities and corporate debt securities is much less liquid. This section will first give a brief picture of the secondary market for each of these types of debt securities. It will then provide an overview of the regulation applicable to the secondary market. Finally, the transparency of the secondary market will be discussed.

\section{A. Trading Activity}

Most fixed income securities in the United States trade in the over-the-counter market.

1. Government securities. The market for US government securities is an active over-the-counter market. ${ }^{92}$ Trading occurs between primary dealers, non-primary dealers, and customers. The market is largely institutional, especially compared to the other segments of the fixed income market. According to the Bond Market

\footnotetext{
${ }^{90}$ The issuer must also provide a list identifying the information made public or required to be made public, and a list of the number of holders of each outstanding class of equity securities held by US residents and the percentage of each class represented by such holdings.

${ }^{91}$ Section 12 of the Securities Act provides for liability for material misstatements or omissions in connection with an offering by means of a prospectus. Section 12 liability also applies in the case of Section 4(2) and Rule 144A offerings.

${ }_{92}$ Treasury securities are actually registered with the New York Stock Exchange but trading is minimal. Federal Reserve Bulletin, 1999.
} 
Association, at the end of 2002, individual investors accounted for only $7.2 \%$ of the amount of US government securities, excluding savings bonds, outstanding. ${ }^{93}$

The majority of trades in government securities are performed by telephone, although broker-dealers use the inter-dealer brokerage system and computer technology to indicated interest to one another, and the use of electronic systems has increased substantially. ${ }^{94}$ Generally, each inter-dealer broker maintains a proprietary system between itself and its primary dealer customers. The primary dealers have access to the inter-dealer broker screens, which they use to trade among themselves. Inter-dealer brokers thus facilitate information flows between primary dealers while providing anonymity to individual trading dealers.

The Federal Reserve manages the National Book-Entry System (NBES), which is an electronic system for recording ownership and legal interests of government securities by depositary institutions. Depository institutions then maintain the records for their customers. Depository institutions can carry out settlement functions for themselves and their customers through NBES. An alternative recording system is maintained by the US Treasury Department. Treasury-Direct is a book-entry securities recording system which can be accessed directly by investors. Securities held through Treasury-Direct are typically held to maturity.

2. GSEs. GSE securities are traded in the over-the-counter market, also largely through inter-dealer brokers. The volume of secondary market trading in GSEs is significantly lower than that in Treasury securities, but still reasonably high compared to the rest of the debt market. As with the Treasury "when issued" market, there is an active "to-be-announced" market in GSE securities, which is essentially a forward or delayed delivery market. Traditionally, trading has been based on telephone discussions. Electronic trading has begun to take hold, particularly in the inter-dealer market. According to the Bond Market Association, there were 12 electronic systems that covered the GSE market in 2000. As a result of the use of electronic platforms, transparency, efficiency and accessibility have improved, at least for the dealer community.

The Bond Market Association has published guidelines governing the mechanics of trading and settling mortgage-backed securities, including GSE pass-through securities. These guidelines, known as the "Good Delivery Guidelines" were developed to facilitate the trading of the to-be-announced market, essentially permitting the securities to trade fungibly by pools according to certain key characteristics enumerated in the Good Delivery Guidelines. The Guidelines have thus contributed to the liquidity of the market, and added to efficiencies in pricing, execution, delivery and settlement.

\footnotetext{
93 www.bondmarkes.com/research.

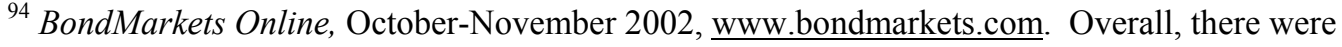
approximately 46 electronic fixed income trading systems based principally in the United States in late 2003. www.bondmarkets.com/research/ecommerce.
} 
3. Municipal securities. The secondary market in municipal securities is small, particularly as compared to the secondary market in government securities. Ironically, this is due, in part, to the large number of issuers and the number of issues. ${ }^{95}$ While electronic trading has made some advances, ${ }^{96}$ the number of issuers and diversity of the securities issued have resulted in a highly illiquid market that is too differentiated to trade electronically. The secondary market in municipal securities is largely a negotiated, dealer market. The municipal bond dealers publish a list of the securities that they wish to sell without quoting a firm price. They then negotiate the price with other dealers.

4. Corporate debt securities. The secondary market in corporate debt securities takes place almost entirely over-the-counter, mostly by telephone. A limited number of corporate debt securities (mostly investment grade bonds) trade on the NYSE and on the American Stock Exchange, and a small number of convertible debt securities trade on NASDAQ. The exchanges have automated systems that support bond trading. The NYSE, for example, uses a system called the Automated Bond System ("ABS") to support corporate bond trading. Subscribers can participate in the bond market using proprietary terminals that provide current quotation and trade information for bonds listed on the NYSE. The ABS also allows electronic order entry and automatically executes trades for matching buy and sell orders.

Electronic trading still has not made tremendous inroads in the secondary market in corporate debt securities. It appears that broker-dealers and their largely institutional investors prefer the "negotiated" aspects of the dealer markets. More importantly, liquidity remains an obstacle. There simply is not enough volume traded electronically to interest large investors. ${ }^{97}$ Finally, as in the municipal market, the differentiation among the debt securities outstanding, including the great variety of structures, credit ratings, coupons, payment schedules and security features, reduces the liquidity of the market, thus hampering the development of electronic trading.

\section{B. Regulation ANd Disclosure in THE SECONDARY MARKets}

US regulation of secondary trading markets varies according to the type of market that is being regulated. As noted above, most fixed income securities in the United States trade in the over-the-counter market. Nevertheless, given the history and evolution of market regulation in the United States, it is worth briefly discussing the regulation of both exchanges and alternative trading systems, as well as the regulation of the over-the counter market.

\footnotetext{
95 As of 2000, there were more than 50,000 municipal securities issuers, more than 1.5 million different issues. See supra, note 7.

${ }^{96}$ Goldman Sachs, Paine Webber and Bear Stearns established a joint venture electronic platform to trade municipal securities. See Maco, supra note 57.

${ }^{97}$ Of course, in both the corporate debt and municipal securities markets, increased electronic trading could enhance liquidity, thereby attracting additional investors.
} 
1. Exchange regulation. As noted above, a limited number of fixed income securities trade on traditional exchanges. The exchanges, which have historically been not-for-profit, member-based organizations, ${ }^{98}$ are operated by the SROs, under the supervision of the SEC. The provisions of the Exchange Act were substantially modified in the Securities Acts Amendments of 1975, in which Congress directed the SEC to facilitate the establishment of a "national market system" to link all markets for particular securities, ${ }^{99}$ and a national system for clearance and settlement.

The Exchange Act defines an "exchange" to mean, "any organization, association, or group of persons, .. which constitutes, maintains or provides a market place or facilities for bringing together purchasers or sellers of securities . ..." "100 Under the Exchange Act, every "national securities exchange" ${ }^{" 101}$ must be registered with the SEC. In order to register with the SEC, an exchange must have rules designed to "prevent fraudulent and manipulative acts and practices, to promote just and equitable principles of trade," and to provide for appropriate discipline of its members for any violations of its own rules or the securities laws." ${ }^{102}$ Under this authority, the exchanges develop rules, which are all subject to SEC approval. Thus, listing requirements, trading and other rules are all established by the exchange, subject to SEC approval. The SEC prescribes record-keeping and reporting requirements, and also conducts inspections and has sanctioning authority. All issuers with securities listed on an exchange must also comply with SEC disclosure and reporting requirements. The exchange has dayto-day responsibility for market surveillance, subject to SEC oversight.

2. ATS. In 1998, the SEC adopted Regulation ATS for the regulation of alternative trading systems. Regulation ATS defines an alternative trading system (ATS) as "any organization, association, person, group of persons, or system that constitutes, maintains, or provides a market place or facilities for bringing together purchasers and sellers of securities or for otherwise performing ... the functions commonly performed by a stock exchange. .., and does not perform any SRO functions, such as setting rules governing the conduct of subscribers other than the conduct of such subscribers' trading, and disciplining subscribers other than by exclusion from trading." Thus, under Regulation ATS, a trading system can conduct trading functions similar to an exchange without registering as an Exchange, as long as it complies with the Regulation and does not perform prohibited SRO functions. An ATS can either select full Exchange Act registration, with all the attendant self-regulatory requirements, or ATS registration, which is a modified form of broker-dealer registration, with additional record-keeping and audit trail obligations. The ATS also must agree to subject itself to inspections and investigations of it or its subscribers by the SEC

\footnotetext{
${ }^{98}$ As in other countries, US exchanges are undergoing a process of demutualization. The NYSE, remains, a member organization, at least for the time being.

${ }^{99}$ Exchange Act, Section 11A.

${ }^{100}$ Exchange Act, Section 3(a)(1).

${ }^{101}$ Exchange Act, Section 6.

${ }^{102}$ Exchange Act, Section 6(b).
} 
or by an SRO of which a subscriber is a member. Rule 301(a) of Regulation ATS, however, exempts from its registration requirements any ATS that is either a registered broker-dealer, a registered government securities broker-dealer, or a bank, as long as that entity limits its securities transactions to government securities as defined in the Exchange Act. The SEC also imposes order access requirements on ATSs to ensure best execution; however, fixed income securities are not included in this rule. ${ }^{103}$

3. OTC markets. The OTC market historically consisted of loosely organized groups of individual dealers that traded securities "over-the-counter," without any formal consolidation. In contrast, while Nasdaq is not an exchange, it does consolidate orders of multiple dealers on a trading screen that is displayed realtime to its members. Other electronic trading platforms now exist as well, alongside traditional over-the-counter-dealer markets. While the OTC markets are not registered with the SEC as exchanges, and consequently are not subject to Exchange Act regulation, they are far from unregulated. Congress effectively mandated SEC regulation of the OTC markets by requiring in 1938 that national securities associations be registered with the SEC. ${ }^{104}$ A national securities association, of which the NASD is the only one, is required to have rules "to prevent fraudulent and manipulative acts and practices [and] to promote just and equitable principles of trade" in transactions in the OTC markets. ${ }^{105}$ In 1983, Congress amended the Exchange Act to prohibit broker-dealers from effecting any transactions in any security unless they are members of a national securities association or effect transactions solely on an exchange of which they are a member. ${ }^{106}$ In addition, even though many corporate issuers are not subject to SEC reporting requirements, all broker-dealers publishing quotations are required to have in their possession and review certain information about the issuer. The purpose of this requirement is to ensure that the broker-dealer has a reasonable basis for believing that the information is accurate and is obtained from reliable sources. They must also agree to make such information available upon request. ${ }^{107}$ Thus, all transactions in the secondary market for fixed income securities, even the OTC markets, are subject to some form of regulation.

The NASD has established Rules of Fair Practice, which govern the obligations of NASD members in recommending securities for sale to customers, as well as rules regarding member conduct. In 1996, the NASD extended its Rules of Fair Practice to all exempt securities other than municipal securities, including many fixed income securities that previously had not been

\footnotetext{
${ }^{103}$ Fixed income securities are generally not included in the order handling rules under Section $11 \mathrm{~A}$ of the Exchange Act.

${ }^{104}$ Exchange Act, Section 15A. While NASDAQ, which is an electronic market for selected OTC securities, is not registered as an exchange with the SEC, it is currently wholly owned by the NASD. The NASD is now in the process of spinning off the NASDAQ as a separate for-profit exchange, and has applied for exchange registration with the SEC.

${ }^{105}$ Exchange Act, Section $15 \mathrm{~A}(\mathrm{~b})(6)$.

${ }^{106}$ Exchange Act, Section 15(b)(8).

${ }^{107}$ Exchange Act, Rule15c2-11.
} 
covered. ${ }^{108}$ The Rules of Fair Practice require that a broker-dealer observe high standards of commercial honor and just and equitable principles of trade in conducting its business. The exchanges and the MSRB have similar rules.

Among the most significant NASD Rules is the "suitability" rule. An NASD member is prohibited from recommending a security to a customer unless he has reason to believe that it is "suitable" to the customer's financial situation and needs. ${ }^{109}$

In accordance with the Rules of Fair Practice, NASD members are also subject to a five percent guideline governing the amount of markup or markdown that they may charge on principal transactions. The purpose of the guideline is to ensure that NASD members earn profits that are fair, equitable, and proportionate to current market prices. ${ }^{110}$ The five percent guideline is not a hard and fast rule; considerations of fairness will take into account a number of factors including the type of security, its availability, its price, and the size of the transaction.

Just like the NYSE, the NASD can inspect and sanction its members. ${ }^{111}$

4. Exchange act reporting. Issuers of securities registered under the Exchange Act are subject to its periodic reporting and disclosure requirements. Under Section 12 of the Exchange Act, every issuer which has securities listed on an exchange, and every issuer with total assets of more than $\$ 1$ million and a class of equity securities with at least 500 record shareholders ${ }^{112}$ is required to file periodic reports with the SEC. Section 13 requires every issuer that has securities registered under Section 12 to file periodic and other reports with the SEC.

Under Section 13 of the Exchange Act, issuers are required to file an annual report on Form 10-K, which must include audited financial statements and quarterly reports on Form 10-Q. In addition, issuers are required to file current reports on Form 8-K, for any month in which certain specified events occurred. Additional filing requirements apply to corporate insiders, and to mergers and takeovers.

In the wake of conspicuous corporate failures and governance weaknesses, including notably the bankruptcies of Enron and WorldCom, Congress adopted the Sarbanes-Oxley Act of 2002, which required the SEC to update and enhance

\footnotetext{
${ }^{108}$ SEC Release No. 34-37588; File No. SR-NASD-95-39, August 20, 1996.

${ }^{109}$ NASD Rule 2310 of the Rules of Fair Practice. See also, Charles Hughes v. SEC, 139 F2d 434 (2d Cir. 1943).

${ }^{110}$ The MSRB has requirements similar to those of the NASD. Municipal bond dealers are required to deal fairly with all persons and not engage in any deceptive, dishonest or unfair practices. They must also give and abide by fair quotations that reflect current market prices, are fair and reasonable and represent bona fide bids and offers.

${ }^{111}$ NASD Rules 8000-10000 of the Rules of Fair Practice. As noted above, however, unlike the NASD and NYSE, the MSRB does not have any inspection or sanctioning authority.

${ }^{112}$ Issuers with total assets of less than $\$ 10$ million are exempt from the registration requirement, if they are not listed on an exchange. Exchange Act, Rule 12g-1.
} 
many of these disclosure requirements. As part of its response, the SEC amended the Exchange Act disclosure rules to expedite and enhance issuer reporting so as to ensure that investors would get more accurate, timely and usable information. ${ }^{113}$

Exchange Act reporting traditionally has not applied to government securities, the securities of GSEs, or municipal securities, as they are all exempt from the registration requirements of the Exchange Act. However, as described above, the GSEs found themselves swept up in the corporate reform initiatives that followed the implosion of Enron. Even though, as a result of market-driven pressures, the GSEs already provided extensive disclosure about themselves, their directors and officers, and their securities, they were subject to intense political pressure to increase their disclosure. In response, in July 2002, Fannie Mae and Freddie Mac agreed to comply with the full panoply of Exchange Act regulation. ${ }^{114}$ As a result, the two entities agreed to file complete, audited 10-K annual reports, 10-Q quarterly reports, and 8-K current event reports. The SEC staff will review and comment on these documents to the same extent that it reviews the filings of other publicly held companies, and has the authority to take enforcement action for material misrepresentations or omissions to the same extent as it does with respect to the filings of other public companies. While the agreement means that the public will have access to comparable information on the two GSEs whose securities are publicly traded, there still will not be Exchange Act information on the many securities that they market publicly. ${ }^{115}$

Further change in the regulation of Fannie Mae and Freddie Mac, including, potentially, full SEC registration and regulation, may yet be forthcoming. On June 9, 2003, Freddie Mac fired its president and chief operating officer and accepted the resignation of two other top executives amid concerns about the proper accounting for derivatives on its financial statements. The company said that its president had altered pages in a personal business diary that had been given to an independent counsel retained by the company's audit committee to investigate the accounting errors. The actions prompted new Congressional hearings and calls for increased disclosure and oversight of Freddie Mac and Fannie Mae. ${ }^{116}$ Legislation was introduced that would shift supervision of the two GSEs to a new office that would be established in the Treasury Department. The scandals, in addition to exacerbating concerns over US

\footnotetext{
${ }^{113}$ Sarbanes-Oxley Act of 2002. See, e.g., Securities Act Rel. 8128A, Acceleration of Periodic Report Filing Dates and Disclosure Concerning Website Access to Reports, Securities Act Rel. 8177A, Disclosure Required by Sections 406 and 407 of the Sarbanes-Oxley Act of 2002.

${ }^{114}$ Pitt, 2002.

${ }^{115}$ In addition, following recommendations issued jointly by the SEC, the Treasury, and OFHEO in January 2003, Fannie Mae and Freddie Mac agreed to make such additional disclosures concerning pool-level information, including, for example, information about loan purpose, original loan-to value ratios, property type, and servicer information.

${ }^{116}$ See, e.g., Freddie Mac in Criminal Investigation, International Herald Tribune, June 11, 2003, Freddie Mac Caught in the Crosshairs, MSNBC, June 11, 2003, Freddie Mac's Accounting Probe, Reuters, UK, June 12, 2003, and FHMC Crisis Puts Pressure on Treasury, Financial Times, June 17, 2003.
} 
corporate governance and accounting standards, have revived the original debate over the proper regulation - and regulator -- of the two GSEs. ${ }^{117}$

As noted above, issuers of municipal securities are not subject to Exchange Act reporting because the securities themselves are exempt from registration. However, in 1994, the SEC amended Rule 15c2-12 to add a continuing disclosure element for purposes of the secondary market. An underwriter subject to the Rule may not purchase or sell municipal securities unless the issuer of those securities has undertaken in writing ${ }^{118}$ to make certain ongoing financial and operating information available on at least an annual basis. This information would be filed with the nationally recognized municipal securities information repository, or NRMSIR, and to the appropriate state information depository (SID), if one exists. In addition, the 1994 amendments introduced a "material event," form of disclosure, similar to Form 8-K for corporate issuers, into municipal securities regulation. Under this provision, there are 11 enumerated events which, if material, require that notice be filed with each NRMSIR or the MSRB and appropriate SID. Finally, the Rule also requires that a notice be filed in the event of a failure of any person to provide the required annual financial information. In that event, the SEC has the authority to bring an enforcement action.

Corporate debt securities, unlike government, GSE, and municipal securities, are not exempt securities and thus would be subject to Exchange Act registration and reporting. However, the periodic and continuous disclosure requirements for post-offering disclosures of corporate debt are limited, compared to the requirements for post-offering disclosures on the equity side. Corporate debt issuers usually are not required to register their securities under Section 12 of the Exchange Act (unless they intend to list the securities on an exchange or on NASDAQ) because they generally have a limited number of holders. For these issuers, who become subject to the Exchange Act pursuant to Section 15(d) of the Exchange Act because they have securities registered under the Securities Act, there is only a limited reporting scheme. Such issuers may stop reporting after they file their first annual report on Form 10-K, if they have fewer than 300

\footnotetext{
117 The GSEs continue to create headlines that have caused many to call into question their special status under US regulation, and to consider whether their regulation by OFHEO is sufficient. On October 29, 2003, Fannie Mae announced that it had made "honest mistakes" in its financial statements, following which OFHEO announced a special review of accounting practices at Fannie Mae. See Accounting Concerns Hurt US Mortgage Giants, AccountancyAge .Com, November 17, 2003. Freddie Mac restated its profits for the past 3 years by $\$ 5$ billion, NYTimes.Com, November 21, 2003, and, on December 9 , 2003 , entered into a consent decree with OFHEO in which it agreed to pay $\$ 125$ million. www.alwaysonnetwork.com. More generally, see, e.g., Regulation of Fannie Mae and Freddie Mac: Mission, Safety \& Soundness, and Disclosure, Mortgage Bankers Association of America, October 2003, Legislation on Fannie Mae and Freddie Mac, Statement of the Shadow Financial Regulatory Committee, www.aei.org/publications, September 22, 2003.

$\frac{118}{11}$ The obligation can also be assumed by a person for whom financial or operating data is presented in the final offering statement.
} 
record holders. ${ }^{119}$ Essentially, the SEC takes that position that, although the securities were originally offered publicly, because the issuer only has a small number of securities holders, they should not be considered a public entity. ${ }^{120}$

\section{Transparency In the Secondary MARKeT}

1. Background. The SEC has long maintained that transparency -- the public dissemination of trade and quote information -- is critical to the fairness and efficiency of the secondary markets. In 1975, Congress embraced this concept with the Securities Act Amendments, which directed the SEC to facilitate the establishment of a National Market System that at its core would be composed of interlinked electronic communications systems. In response, the SEC, along with the SROs, developed systems to enhance market transparency, including the consolidated quotation system, consolidated transaction reporting, and the Intermarket (ITS) system, which links the exchanges and the OTC market. Similarly, the order handling rules that the SEC imposed on NASDAQ in 1996 greatly increased the amount of information available to the public. ${ }^{121}$ As the markets evolve in response to globalization and technological advances, the SEC continues to strive to balance the sometimes conflicting goals of market transparency, which tends to reduce fragmentation and increase centralization, and market competition. ${ }^{122}$

The fixed income market in the United States has historically been substantially less transparent than the equity market. Under former SEC Chairman Arthur Levitt, in 1998, the SEC began reviewing the transparency of the US debt markets, with a special focus on the market for corporate debt securities. This section of the Report will look at the transparency of the secondary market in the four principal sectors of the US fixed-income market, government securities, GSE securities, municipal securities and corporate debt securities.

2. Government securities. The market in the United States for government securities is generally considered to be quite transparent, particularly in comparison to the market for other fixed-income securities. ${ }^{123}$ GovPX is an electronic system that was founded in 1990 by all the primary dealers and four inter-dealer brokers

\footnotetext{
${ }^{119}$ Section 15(d) of the Exchange Act requires any issuer that has filed an effective registration statement under the Securities Act of 1933 to file periodic reports with the Commission as prescribed by Section 13 of the Exchange Act, unless the securities as to which the Registration Statement is effective are held of record by fewer than 300 persons. This is almost always true of private-label issuers of mortgage-backed securities.

${ }^{120}$ Private label issuers of mortgage-backed securities also are required to file only a modified Form 10-K, which does not have to include financial statements. Such issuers do, however, sometimes continue to provide information to their holders even after their reporting obligations are discontinued.

${ }^{121}$ Exchange Act Rule 11Ac1-4, which requires market makers to publish quotations for any security when it is responsible for more than 1 percent of its aggregate trading volume, and to make publicly available any superior prices that the market maker privately quotes through certain electronic communications networks. ${ }_{122}$ See IOSCO, 2001.

${ }^{123}$ IMF, supra note 3. See, also, Levitt, 1998, supra note 24.
} 
serving the US government securities market. It provides real-time quote and transaction data, including price and volume, for Treasury bills, notes, bonds, and government agency securities. GovPx disseminates the composite information to its subscribers for a fee. This centralized reporting and dissemination system produces an extremely transparent government securities market.

3. GSEs. AgencyPX, a joint venture of GovPX and Garban-Intercapital plc, publishes real time inter-dealer bids and offers, last trade, yield spreads, and history and news for the US government agency market. In addition, Bloomberg LP and other third party vendors publish average daily price quotations for TBA trades, which include only generic securities. Daily pricing of such trades is also available from a dealer network. ${ }^{124}$ Finally, Fannie Mae and Freddie Mac report all buy and sell activity on their websites and to the SEC, which then makes the information available to the public.

4. Municipal securities. The transparency of the municipal securities market increased in the 1990s. Municipal securities transactions are reported under the rules of the MSRB. ${ }^{125}$ The MSRB publishes a daily report that includes the high, low and average price (and total par) for all municipal securities traded the previous day. The Bond Market Association makes the information available to the public on its website, and it also is available to the SEC, the NASD and the other relevant agencies for surveillance and enforcement purposes. ${ }^{126}$ The MSRB also has indicated that it is considering a move from next-day dissemination to real-time dissemination by the middle of $2004 .{ }^{127}$

5. Corporate debt securities. The corporate debt securities market was historically not a transparent market. This was due in part to the enormous differentiation of the securities themselves, and the fact that holders of corporate debt were largely institutional investors who, it was believed, were able to look out for themselves.

As noted above, the SEC began reviewing the transparency of the debt market in 1998 and issued a call for greater transparency in the corporate debt market. Chairman Levitt called for the NASD to: (i) adopt rules requiring all transactions in US corporate debt securities to be reported to the NASD, and to develop a system to receive and distribute transaction prices on an immediate basis; (ii) create a database of transactions in corporate bonds to enhance the surveillance and supervisory ability of the NASD and other regulators; and (iii)

\footnotetext{
${ }^{124}$ SEC Staff Report on Enhancing Disclosure in the Mortgage-Backed Securities Markets, supra note 23, p. 16.

${ }_{125}$ MSRB Rule G-14.

${ }^{126}$ The SEC approved the recent increases in transparency despite opposition from the Bond Market Association which raised concerns that the move would reduce market liquidity, particularly for lessfrequently traded bonds. See, Comment Letter to Jonathan G. Katz, Secretary, SEC, May 9, 2003. In 1994, the SEC proposed that municipal securities dealers disclose on transaction confirmations the amount of their mark-up in so-called "riskless principal" transactions. Not surprisingly, the industry vigorously opposed the rule, which ultimately was not adopted. See SEC Rel. No. 34-33743, 1994, and Comment Letter of Fenn Putman, Chairman, Public Securities Association, June 21, 1994.

${ }^{127}$ MSRB Notice 2003-3, February 3, 2003.
} 
create a surveillance program to deter misconduct and foster investor confidence in the corporate debt market. ${ }^{128}$ In response, the NASD developed the Trade Reporting and Compliance Engine (TRACE).

TRACE was initiated on July 2, 2002 using a phased-in approach to corporate bond reporting. In the initial phase, the SEC required all broker-dealers who are NASD members to report eligible secondary market, over-the-counter transactions in corporate debt securities to TRACE. TRACE-eligible securities include most corporate debt securities issued in the United States, whether issued by US or foreign corporations, and whether registered with the SEC or issued under Section 4(2) of the Securities Act of 1933 and sold under Rule 144A. ${ }^{129}$ As of October 1, 2003, transaction information must be reported within 45 minutes of the time of execution. ${ }^{130}$ Prices on these trades are then disseminated, subject to certain restrictions and limitations. For each bond transaction that is subject to dissemination, TRACE displays the execution date and time, the quantity, the price and the yield. TRACE also shows whether the price reflected a commission, any special settlement or condition, and whether the trade was reported late.

TRACE enabled investors for the first time to receive accurate information on the actual sale price of US corporate securities. In addition, they are able to view 90 days of transaction history, 90 days of daily highs and lows, and 52 weeks of weekly highs and lows for those bonds approved for dissemination. ${ }^{131}$

During its first phase, TRACE received transaction reports on approximately 25,000 corporate bonds, and disseminated price information for the largest issues of investment grade bonds. The second phase of TRACE, which was implemented on March 3, 2003, significantly expanded the pool of corporate bonds reported to the public on TRACE to 4,650 from 500. On April 14, 2003, the NASD announced that TRACE began disseminating an additional 120 tripleB-rated corporate bonds. With this expansion, TRACE is reporting transaction activity responsible for approximately 75 percent of the market volume. ${ }^{132}$

In addition to the TRACE reporting system, the NASD has a designated website, NASD BondInfo, which provides additional information about corporate debt securities. This site contains basic descriptive information on many

\footnotetext{
128 See, Levitt, 1998, supra note 24.

129 TRACE-eligible securities do not include sovereign debt, GSE-debt, mortgage or asset backed securities, and most municipal securities. Municipal securities transactions are reported under the rules of the Municipal Securities Rulemaking Board. Note as well that transactions in unregistered securities sold pursuant to Rule 144A are subject to reporting for regulatory and surveillance purposes only and are not disseminated on TRACE.

${ }^{130}$ NASD Rule 6230(a). SEC Release No. 34-48056, June 18, 2003. The NASD has stated that it expects to recommend further reductions in trade reporting times in the future. SEC Release No. 34-47856, May 14, 2003.

${ }^{131}$ Dissemination of transaction information is available to NASD members on a real-time basis for a fee through the Bond Trade Dissemination Service.

${ }^{132}$ NASD News Release, April 14, 2003.
} 
corporate bonds, as well as individual and summary transaction data gathered by the NASD.

\section{REGULATION OF INTERMEDIARIES}

Section 15 of the Exchange Act requires all broker-dealers, unless they transact business in exempt securities, to be registered with the SEC. ${ }^{133}$ However, as described below, even broker-dealers who trade only government securities must now register with the SEC. Municipal securities broker-dealers have to register as well. Pursuant to the Exchange Act, the SEC has imposed a comprehensive regulatory scheme on brokerdealers, which includes licensing qualifications, financial responsibility rules, customer protection rules, sales practice rules, and best execution requirements. The following section of this report provides a brief overview of broker-dealer regulation; it does not purport to be a comprehensive description.

\section{A. BROKER-DEALER REgISTRATION}

Section 15(a) of the Exchange Act prohibits any person from engaging in business as a broker-dealer, unless he does business solely intra-state or solely in exempt securities. However, as described above, the Government Securities Act of 1986 imposed a registration requirement on broker-dealers who deal in government securities, provided that they are not banks or other "financial institutions." Broker-dealers who limit their securities activities to government securities register under Section $15 \mathrm{C}$ of the Exchange Act, unless they are banks or other financial institutions, in which case they must file a notice with their appropriate federal regulator. General purpose brokerdealers that conduct a government securities business must file a notice with the SEC. Similarly, broker-dealers who deal in municipal securities must register as generalpurpose broker-dealers under Section 15(b) of the Exchange Act, unless they conduct their business solely intra-state, or are banks, in which case they must register under Section 15B as municipal securities dealers. Licensing requirements in all cases include proficiency tests as well as capital adequacy requirements.

\section{B. FinANCIAL ReSponsibility}

1. Net capital. Under Exchange Act Rule 15c3-1, broker-dealers are required to maintain minimum net capital adequate to ensure that their assets are sufficiently liquid to meet their obligations to customers, if the broker-dealer were to go out of business. In the United States, there are relatively fixed standards for determining capital charges, largely based on the type of securities activities that the broker-dealer conducts, and only limited use of value at risk models and internal risk models for setting capital. The capital rules do not take into account hedged positions on a portfolio basis, which is the way most dealer firms tend to

${ }^{133}$ Section 15(b) of the Exchange Act. 
manage their own credit and market risks. Broker-dealers that clear and carry customer accounts must maintain a minimum of $\$ 250,000$ in net capital. Other categories of broker-dealers can maintain lower capital levels.

2. SIPC. The Securities Investor Protection Act of 1970 created a non-profit membership corporation, funded by assessments on broker-dealer revenues, that provides specific limited protection for customers of broker-dealers that are forced to liquidate.

\section{Customer Protection Rules}

Rule 15c3-3 (the customer segregation rule) provides protection for customers of broker-dealers by requiring broker-dealers to establish standards for obtaining physical possession and control of fully-paid securities and excess margin securities carried for a customer's account and to maintain certain required levels of reserves when using customer funds. The rule also requires broker-dealers to make a weekly computation of customer "credits" and "debits" and to maintain an amount equal to any excess "credits" in a special reserve bank account for the exclusive benefit of customers.

\section{Sales Practice Rules}

The sales practice rules that apply to broker-dealers are based on the antifraud provisions of the securities laws, which are described in more detail below. As such, they apply to all broker-dealers who transact business in any type of security. Sales practice rules are based on the duty of fair dealing that every broker-dealer owes to its customers, and address conflicts of interest that may arise between a broker-dealer and its customers. In addition to the rules described below, the SROs also have rules to ensure fair dealing. ${ }^{134}$

1. Confirmation rule. Under Rule 10b-10 of the Exchange Act, a broker-dealer must provide written confirmations of each transaction. The confirmations must include disclosure of whether the broker-dealer was acting as a broker for the customer, a dealer for its own account, or as a broker for another customer. ${ }^{135}$

2. Churning and scalping. Broker-dealers are also prohibited under the antifraud laws from "churning" or "scalping" an account. Rule 15c1-7 of the Exchange Act prohibits a broker-dealer from engaging in any transaction in OTC securities which is "excessive in size or frequency in view of the financial resources and character of the account." Similarly, broker-dealers may not, without providing adequate disclosure, recommend a security that they have previously purchased and then sell it at a profit to the customer after the recommendation.

3. Suitability and know your customer rules. Broker-dealers are subject to both suitability and know-your-customer rules. Suitability requirements are based on

\footnotetext{
${ }^{134}$ See, e.g., MSRB Rule G-17.

${ }^{135} \mathrm{See}$, also, MSRB Rule G-15.
} 
the theory that the broker-dealer is acting as the agent for his customer and is therefore prohibited from recommending a security to the customer unless it is "suitable" in light of the customer's financial situation and objectives. ${ }^{136}$ Historically, broker-dealers did not have separate know-your-customer obligations, arguing successfully that such requirements were unnecessary in light of the nature of the securities industry, which is generally perceived as less subject to money-laundering than the banking industry, and duplicative of the already existing suitability requirements. However, following September 11, 2001, Congress passed the Patriot Act of 2001, which mandated the SEC and the Department of Treasury jointly to prescribe know-your customer rules and identification requirements for securities firms.

4. Best execution rules. The duty of best execution is derived from the common law obligation of loyalty owed by a broker-dealer to its customer. It requires a broker-dealer to seek to obtain the most favorable terms available under the circumstances for its customer orders. ${ }^{137}$ The obligation applies, even when the broker-dealer is acting as principal in the transaction. The SRO rules also include a duty of best execution. For example, in any transaction for or with a customer, NASD members must use "reasonable diligence" to determine the best market for a security and buy or sell the security in that market, so as to obtain the most favorable price available given the market conditions. ${ }^{138}$

Broker-dealers that are exchange specialists or Nasdaq market makers are required to comply with particular rules regarding publishing quotes and handling customer orders. These rules, which include the "Quote Rule" and the "Limit Order Display Rule," increase the information that is publicly available concerning the prices at which investors may buy and sell exchange-listed and Nasdaq equity securities. ${ }^{139}$

\footnotetext{
${ }^{136}$ See, e.g., NASD Rule 2310 and MSRB Rule G-19.

${ }^{137}$ By definition, best execution is to the customer advantage.

${ }^{138}$ NASD Rule 2320. See, also, NASD Notice to Members 01-22, April 2001, "If a broker/dealer, however, receives an order routing inducement, such as payment for order flow, or trades as principal with customer orders, it must not let that inducement interfere with its duty of execution nor may that inducement be taking [sic] into account in analyzing market quality.” See also, MSRB Rule G-30.

${ }^{139}$ The Quote Rule requires specialists and market makers to provide quotation information. A specialist or market maker may only trade at better prices in an ECN, if the ECN itself publishes the improved prices and makes those prices available to the investing public. Thus, the Quote Rule ensures that the public has access to the best prices at which specialists and market makers are willing to trade even if those prices are in private trading systems. The Limit Order Display Rule requires that specialists and market makers publicly display a limit order they receive from customers if it is for a price that is better than the specialist's or market maker's quote. The rule benefits investors because the publication of trading interest at prices that improve specialists' and market makers' quotes present investors with improved pricing opportunities.
} 


\section{MARKET INTEGRITY ISSUES}

\section{A. Antifraud Provisions of the Securities LAWS}

Whether or not a security, including a fixed income security, is subject to registration under the US federal securities laws, and whether or not the security is traded on an exchange, the antifraud provisions of the federal securities laws apply to transactions in the security. The antifraud provisions thus apply to government, GSE, municipal and corporate debt securities, even though they are all traded almost entirely over-the-counter. ${ }^{140}$

The principal antifraud provisions are Section 17(a) of the Securities Act, Section 10 (b) of the Exchange Act, and Rule 10b-5 thereunder. ${ }^{141}$ These provisions generally prohibit any person from making a false or misleading statement of material fact, and from omitting to state a material fact that is necessary in order to make any statements made not misleading. To be considered material, there must be a substantial likelihood that disclosure of the omitted fact "would have been viewed by the reasonable investor as having significantly altered the total mix of information made available." "142 These provisions are enforced by the SROs (other than the MSRB which has no enforcement powers), and the SEC. There is also a private right of action under the antifraud laws in the United States.

Section 10(b) and Rule 10b-5 are the securities provisions that form the basis for many of the SEC's insider trading enforcement actions. In order for the SEC to bring an insider trading action under Section 10(b) and Rule 10(b)-5, the SEC must be able to prove that the person acted fraudulently or deceitfully, that is, with scienter, that the transaction was "in connection with" the purchase or sale of a security, and that the insider (or tippee) was in possession of material non-public information and traded (or tipped) in breach of a duty or relationship of trust or confidentiality. These interpretations, which are derived largely from US federal court decisions, have made it more difficult for the SEC to bring an action for insider trading in the fixed income securities market. Because debt instruments are contractual in nature, the necessary duty or relationship with the securities holders may be lacking. While this question has never been resolved, the SEC does not appear ever to have brought an insider trading case in connection with fixed income instruments.

In addition to the general antifraud provisions, Section 11 of the Securities Act establishes liability for misstatements or omissions of material fact in registered

\footnotetext{
${ }^{140}$ See, e.g., Statement of the Commission Regarding Disclosure Obligations of Municipal Securities Issuers and Others, SEC Rel. No. 33-7049, SEC Rel. No. 34-33741, 1994.

${ }^{141}$ Additional antifraud provisions include Section 9(a) of the Exchange Act, which prohibits particular manipulative practices regarding securities registered on a national securities exchange, and Sections 15(c)(1) and 15(c)(2) which apply expressly to the over-the-counter market. Section 15(c)(1) prohibits broker-dealers from effecting transactions in, or inducing the purchase or sale of, any security by means of "any manipulative, deceptive or other fraudulent device," and Section 15(c)(2) prohibits a broker-dealer from making fictitious quotes.

${ }^{142}$ TSC Industries, Inc. v. Northway, Inc., 426 US 438, 449 (1976).
} 
offerings. An investor can sue anyone who signed the registration statement, ${ }^{143}$ the directors of the issuer, and the underwriter. The issuer has absolute liability for any such misstatements or omissions, while the others have the option of a defense of due diligence. Under Section 18 of the Exchange Act, an investor can sue any person who makes, or causes to be made, a false or misleading statement in any report or other document filed under the Exchange Act, as long as the investor can prove reliance on such statement and that the price involved was affected by such statement.

\section{B. MARKet Manipulation}

In the United States, market manipulation is generally considered to be a form of fraud, and is enforced by the SEC under the general antifraud provisions of the federal securities laws. There are also specific securities laws and rules that expressly prohibit particular forms of market manipulation. These too, like the antifraud provisions, apply to fixed income securities to the same extent that they apply to equity securities. Sections 9 and 10(a) of the Exchange Act prohibit particular manipulative activities in connection with exchange-listed securities, and Section 10(b) authorizes the SEC to adopt rules to prohibit manipulation with respect to any security. ${ }^{144}$ Section $15(\mathrm{c})$ of the Exchange Act also expressly prohibits the use of manipulative or deceptive devices in connection with securities transactions, including government and municipal securities, and authorizes the SEC to issue rules thereunder. ${ }^{145}$ The SEC has promulgated rules under Section 15(c) that expressly apply to manipulation in over-the-counter transactions.

In April and May of 1991, the US government securities market was shaken by several widely publicized "short squeezes" of the Treasury two-year note in which an apparent shortage caused their yields to fall substantially below those for other Treasury securities. Following investigations by the SEC and the Department of Justice, Salomon Brothers admitted to submitting unauthorized customer bids and failing to report certain positions as required. These events led to a joint review of the government securities market by the Treasury, the SEC and the Federal Reserve Board. Following their review, the three agencies made a number of recommendations to improve the integrity of the government securities market. ${ }^{146}$ As a result, the accessibility of Treasury auctions has been broadened, the requirements for becoming a primary dealer have been eased, customer bids are now subject to spot-checking by the FRBNY to ensure their authenticity, and all customer auction awards greater than or equal to $\$ 500$ million are

\footnotetext{
143 The registration statement must be signed by the issuer, and by its principal executive, financial and accounting officers, and at least a majority of the board of directors. In 1981, the SEC adopted the same signature requirements for the Form 10-K annual report. Pursuant to the Sarbanes-Oxley legislation of 2002, the SEC now requires that such filings be accompanied by certifications from the "signers" that to the best of their knowledge the statements contained therein are true.

${ }^{144}$ Pursuant to this authority, the SEC has adopted Regulation M, which sets forth quite specifically the line demarking, on the one hand, permitted activity in the market during the distribution of a security for purposes of stabilizing its price, and, on the other, prohibited, manipulative activity. Exchange Act Regulation M, replacing Exchange Act Rules 10b-6, 10b-7, and 10b-8, 1997.

${ }^{145}$ The SEC is expressly directed to consult with the US Treasury Department and other appropriate regulatory agencies in considering rules relating to transactions in government securities.

${ }^{146}$ Joint Report on the Government Securities Market. Department of Treasury, SEC, Federal Reserve Board, Washington DC, Government Printing Office, January 1992.
} 
confirmed directly with the customer. The automation of the auction procedure also has been enhanced. In addition, Congress enacted the Government Securities Act Amendments of 1993 which, among other things, gave to the Treasury Department the authority to require holders of large positions in a particular security to report on their positions in the event of a shortage.

\section{EnForCEMENT Authority}

The integrity of the US markets is as much a product of an active enforcement environment as it is of the laws and rules that prohibit violations. As described above, the SROs (other than the MSRB) have front-line surveillance and enforcement responsibility. They conduct surveillance, on a daily basis, of the operations of the markets and the conduct of their members. They also have an aggressive inspection program. The SEC supervises the activities of the SROs, conducts a limited amount of direct market surveillance, and itself retains broad inspection and enforcement authority.

Unlike many other supervisory authorities, both within and outside of the United States, the SEC has broad law enforcement authority. The SEC can compel the production of information, including both documents and testimony, from any person, located any where within the United States. The SEC does not need to obtain court approval to issue a subpoena. In addition, the SEC can conduct surprise, as well as routine, inspections, and obtain on demand the records of any SEC-registered entity. As described above, the SEC can bring civil as well as administrative enforcement actions, and had a broad range of penalties at its disposal. It also can ask a court, ex parte if necessary, to freeze the funds of any person it suspects of violating the federal securities laws. These comprehensive enforcement powers, along with the SEC's reputation as an aggressive prosecutor, have contributed to the integrity of the US markets. The deterrent effect of the SEC's enforcement powers is complemented by a system of private litigation in which investors in many cases can bring a private action, including a class action, for violation of the securities laws. While the SEC cannot bring a criminal action for violating the US securities laws, the US Justice Department can do so and frequently works cooperatively with the SEC in this regard. Recent years have seen an increase in the frequency of such criminal actions.

The SEC under Chairman Arthur Levitt was particularly active in bringing municipal securities enforcement cases. ${ }^{147}$ A substantial number of enforcement actions were brought to enforce the enhanced disclosure requirements under Rule 15c2-11. These cases focuses on the municipal issuer as well as the underwriter. ${ }^{148}$ In addition, the SEC's Enforcement Division focused on the new rule prohibiting "pay to play" in the

\footnotetext{
${ }^{147}$ An SEC official noted in October 2000 that in the previous six years the SEC has brought over 100 enforcement actions in the municipal securities area. Stephen J. Weinstein, Municipal Securities in the Information Age: Responsibilities under the Federal Securities Laws, October 3, 2000.

${ }^{148}$ See, e.g., In the Matter of the City of Miami, Florida, Cesar Odio and Manohar Surana, Securities Act Rel. 7741, Exchange Act Rel. 41896, A.P. File No. 3-10022 (September 22, 1999); In the Matter of Albert Adamczak, C.P.A., Exchange Act Rel. 42743, A.P. File No. 3-10196; SEC v. David W. McConnell and Charles P. Morrison, Civ. Action No. 00CV2261 (E.D. Pa.), Lit. Rel. 16524 (May 2, 2000). Many municipal cases can be found on the SEC's website at www.sec.gov.
} 
municipal securities market ${ }^{149}$ and also brought a number of "pay to play" cases. ${ }^{150}$ Finally, the SEC also brought a large number of "yield burning" cases, in which it alleged that underwriters had charged excessive mark-ups in connection with advance refundings. ${ }^{151}$ Generally speaking, the SEC has brought fewer cases alleging fraud and manipulation in the US fixed income market than in the equity market. In considering amendments to Rule 15c2-11, which were aimed at reducing fraud in the penny stock market by requiring broker-dealers to possess certain information about an issuer before publishing quotations for its securities, the SEC noted that, "[ $\mathrm{t}]$ he fraud and manipulation that we have observed in the microcap securities have not been evident in the fixedincome market. In addition, non-convertible debt securities, non-participatory preferred stock, and investment grade asset-backed securities generally trade at prices and in denominations that make them less likely targets for manipulation. Further, the type of issuer information required by the Rule is much less relevant to the pricing and trading of these types of securities. ${ }^{152}$ While it may be true that there are fewer instances of fraud and manipulation in the fixed-income market, it is equally possible that the SEC has a more difficult time detecting and investigating such abuses due to the nature of the market, and less interest in doing so due to the nature of the investor base.

\section{REGULATION OF MARKET INFRASTRUCTURE}

The Securities Acts Amendments of 1975 gave the SEC authority over transfer agents and clearing agencies. Regular settlement for corporate and municipal trades is $\mathrm{T}+3$. Most US government securities settle on $\mathrm{T}+1$.

The Government Securities Clearing Corporation (GSCC) has traditionally been the clearing utility and central counterparty for trade comparison and netting for US government securities and government agency securities. The Mortgage-Backed Securities Clearing Corporation (MBSCC) has conducted the same functions for mortgage-backed securities. MBSCC recently merged into the GSCC and the name was changed to the Fixed Income Clearing Corporation (FICC). ${ }^{153}$ The GSCC and the MBSCC operate as separate divisions of the FICC, continuing to offer their own productspecific services to their members. The FICC is a wholly-owned subsidiary of the Depository Trust Clearing Corporation (DTCC) and is registered with and supervised by the SEC as a clearing agency. The National Securities Clearing Corporation (NSCC) is the clearing agent for most corporate and municipal fixed income transactions. The NSCC is also a wholly owned operating subsidiary of the DTCC and is also an SEC-

\footnotetext{
${ }^{149}$ MSRB Rule G-37 which generally prohibits a dealer from engaging in municipal securities business with an issuer within two years after certain contributions to an official of such issuer made by the dealer.

${ }^{150}$ See, e.g., Staff Report on Transactions in the Marine Protein Corporation Industrial Development Revenue Bonds, Exchange Act Rel. No. 15719 (April 11, 1979) .

${ }^{151}$ See "SEC Settles With 10 Brokerage Firms as Part of Global Resolution of Yield Burning Claims," April 6, 2000.

152 Proposed Rule: Publication or Submission of Quotations Without Specified Information, Rel. 34-41110. The amendments have not been adopted.

${ }^{153}$ For more information on the US clearance and settlement entities see the FICC and DTCC websites, www.ficc.org and www.dtcc.org, respectively.
} 
registered clearing agency. The FICC is expecting to implement real-time trade matching for corporate and municipal bonds beginning in the last quarter of 2003. Clearance and settlement remain with the NSCC. DTCC is entirely industry-owned. Its shareholders are primarily banks, broker-dealers, and exchanges. Following the clearing process, securities must be exchanged for funds, or settled, on either a gross or a net basis. The Depository Trust Company (DTC) settles most trades in most corporate securities in the United States. DTC is a wholly owned subsidiary of DTCC and is a member of the Federal Reserve System and a registered clearing agency with the SEC. It is the world's largest securities depository and was created in 1973 in response to the paperwork crisis that the growth of the markets had produced. DTC immobilizes stock certificates by maintaining them in a central location; transfers are recorded electronically. ${ }^{154}$

Government securities are settled through depository institutions acting as agents for non-bank dealers. ${ }^{155}$ Settlement is highly concentrated in a few depository institutions known as clearing banks. Currently, only two banks, JP Morgan Chase and The Bank of New York, provide a full range of settlement services. These include transfer against funds, the provision of intraday credit to facilitate settlement, position management services for primary dealers (including matching settlement instructions with incoming securities, and real-time reporting of transactions), and overnight and term financing through triparty repurchase agreements. ${ }^{156}$ The settlement services provided by these two banks account for more than $75 \%$ of the value of Fedwire settlement activity. The Federal Reserve and the US Treasury also rely heavily on the services of the two clearing banks.

The events of September 11, 2001 caused widespread disruption to the US financial markets. The US fixed income market, including the government securities market, was closed for two days. ${ }^{157}$ Clearance and settlement of government securities transactions was highly disrupted and there was an unusual number of settlement fails, ${ }^{158}$ particularly as the two principal locations of the Bank of New York were both destroyed in the attacks. ${ }^{159}$ In addition, several of the brokerage firms that had arranged the transactions had been located in the destroyed buildings, and telecommunication facilities were severely impaired.

\footnotetext{
${ }^{154}$ DTC and the NSCC were originally established in response to the paperwork crisis that developed in the US securities industry in the late 1960s. DTC was created to immobilize securities for broker-dealers and banks, and complete the book-entry delivery process. In addition, the exchanges each established clearing organizations to settle trades through a multilateral netting process. In 1976, the various clearing organizations were merged into one organization, the NSCC.

${ }^{155}$ Inter-bank settlement occurs through the Fedwire securities transfer system.

${ }^{156}$ These transactions involve the secured financing of broker-dealer securities inventories by a large number of cash investors. All major broker-dealers rely on triparty repo financing and it accounts for nearly \$1 trillion per day in transactions. US SEC, 2002.

${ }^{157}$ US equity markets were closed for four days.

${ }^{158}$ FRBNY Policy Review, 2002. Although trading stopped shortly after the first attack at 8:46 am, purchases and sales of approximately $\$ 80$ billion of Treasury and related securities, and about $\$ 500$ billion in repurchase agreements had already been negotiated.

${ }^{159}$ Staffs of the Federal Reserve, the New York State Banking Department, the Office of the Comptroller of the Currency, and the SEC, Summary of "Lessons Learned" from Events of September 11 and Implications for Business Continuity," Discussion Note prepared for 26 February 2002 Meeting at the FRBNY, February 13, 2002.
} 
Following September 11, the SEC, the Federal Reserve and US Treasury held discussions with market participants about the vulnerabilities in the settlement system for government securities. Concerns existed over operational risk, financial risk (if a clearing bank's financial condition were to become impaired), and structural risk ( if one of the two clearing banks ere to exit the market). In response to these discussions, the SEC and the Federal Reserve Board issued a white paper setting forth issues relating to the possibility of establishing an industry utility to conduct settlement. ${ }^{160}$

\section{RATING AGENCIES AND THEIR ROLE}

Credit ratings have been used most widely and for the longest period of time in the United States. Their use has grown in tandem with the development of increasingly complex financial instruments, which individual investors find difficult to assess. The purpose of credit ratings is to provide objective and independent opinions of relative credit risk. There are three dominant rating agencies in the United States, Moody's Investors Service, Standard and Poor's, and Fitch, Inc. Moody's and Standard and Poor's rate all taxable securities sold in the US domestic market that are registered with the SEC, whether or not they are compensated by issuer. ${ }^{161}$

Credit rating agencies in the United States are virtually unregulated. They are not subject to any federal reporting requirements nor are they required to have written rules concerning the training and hiring of employees. ${ }^{162}$ The SEC has developed a concept called a, "nationally recognized statistical rating organization" (NRSRO). NRSRO status essentially means that the rating agency has some degree of recognition in the market. NRSRO status is significant because it is the trigger for a number of regulatory and other events. For example, when calculating a firm's net capital, a favorable capital charge may accrue to investments in those instruments of issuers that have received a certain rating from an NRSRO. Institutional investors may be required to hold instruments of certain NRSRO status in their portfolios. Also, downgrades in NRSRO ratings are frequently embedded in loan and other financing agreements as a trigger requiring acceleration of payment. The SEC currently has granted NRSRO status only to the three rating agencies identified above and to Dominion Bond Rating Service Ltd.

Credit rating agencies received significant criticism in the wake of the recent corporate scandals. It was frequently noted in the financial press, for example, that credit rating agencies had been well behind the curve in their ratings of many failing companies, including Enron. Politicians, government officials, and the financial press raised questions about the rating agencies' independence and the conflicts of interest that

\footnotetext{
${ }^{160}$ US SEC, 2002

${ }^{161} \mathrm{IMF}, 1998$.

162 The SEC has required credit rating agencies to register as investment advisers; however, their credit ratings business is not subject to any regular reporting requirements.
} 
they faced. The Sarbanes-Oxley legislation of 2002 directed the SEC to study the issue, ${ }^{163}$ and the SEC held public hearings in November of that year.

In January 2003, the SEC produced a report, which it submitted to Congress, in which it identified several areas of concern. These included: (i) a need for improved information flow regarding the rating process; (ii) potential conflicts of interest from two sources in particular - where a purchaser pays for the rating, and where the agency has developed an ancillary fee-based business; (iii) alleged anticompetitive or unfair practices by the agencies; (iv) potential regulatory barriers to entry; and (v) the need for ongoing regulatory oversight of the agencies.

On June 4, 2003, the SEC issued a Concept Release seeking comment on the role of credit rating agencies in the operation of the securities markets. Among other things, the SEC has sought comment on whether credit rating agencies should continue to be used for regulatory purposes under the US securities laws, and, if so, the degree of oversight to which they should be subject. ${ }^{164}$

\section{COLLECTIVE INVESTMENT SCHEMES}

In the United States, many individual investors who wish to invest in fixed income securities do so through mutual funds which specialize in such instruments. In addition to money market mutual funds, ${ }^{165}$ the bond fund market in the United States consists of a range of specialized funds including, US government funds, Ginnie Mae funds, corporate bond funds, income-bond funds, high-yield bond funds, municipal bond funds, and global bond funds. ${ }^{166}$ According to the Investment Company Institute, which is a trade association for the mutual fund industry, there were approximately 2,040 bond funds at the end of 2002, -- approximately one fourth of the total number of mutual funds at that time. In the United States, bond funds are regulated as mutual funds, which are collective investment schemes strictly regulated by the SEC pursuant to the Investment Company Act of 1940. ${ }^{167}$ The Investment Company Act provides detailed prudential rules regulating the operation of mutual funds.

Bond funds are popular in the United States for the same reasons as equity funds. They provide investors with a professionally managed, diversified portfolio which demand only a modest minimum investment, and offer a number of convenient features. In addition, bond funds that specialize in municipal securities offer investors the benefit

\footnotetext{
${ }^{163}$ Section 702(b) of the Sarbanes-Oxley Act of 2002.

${ }^{164}$ SEC Concept Release: Rating Agencies and the Use of Credit Ratings under the Federal Securities Laws, SEC Rel. 33-8236, 34-47972, IC-26066, June 4, 2003.

${ }^{165}$ Rule 2(a)(7) restricts the investment portfolio of a fund that holds itself out as a money market fund to certain kinds of instruments.

166 The Investment Company Institute estimated in 1997 that all bond mutual funds in the United States had approximately $\$ 635.6$ billion in assets, and were approximately 18 percent of mutual fund assets. Reid, 1997.

${ }^{167}$ Bond funds also may be established as hedge funds, outside the purview of the Investment Company Act.
} 
of tax-exempt income. ${ }^{168}$ Because of their attractiveness to individual investors, mutual funds facilitate the development of an investor base. In addition, to the extent that mutual funds for money market instruments exist, they can help promote the development of a broader fixed income market. In the United States, for example, mutual funds are the most significant holder of money market instruments. ${ }^{169}$

Pursuant to the Investment Company Act and the SEC's rules, bond mutual funds must meet certain operating standards, comply with the antifraud provisions, and disclose material information to investors, both initially and on a periodic basis. Because of their special form of regulation, investment companies raise a series of unique regulatory issues. Predominant among them is the fair measurement of the net asset value of interests in the fund, and the accurate representation of returns.

The Investment Company Act requires mutual funds to calculate their net asset values, at least once daily, by using the market value of their portfolio securities when market quotations for those securities are "readily available." Pricing bond fund portfolios can be more difficult than for an equity portfolio because there are few last sale quotes available for many debt securities. ${ }^{170}$

In most cases, a bond fund will contract with a pricing service such as Standard \& Poor's which provides daily pricing information on the bonds a fund owns. These services collect information from dealers on trades they either made or know about for issues at various points on the yield curve. Based on this information, they will then draw a yield curve for each different rating category from which they can then price any comparably rated instrument regardless of its remaining life. The yield curve or as it is also called, matrix pricing, is quite accurate. If a bond fund gets a price for an instrument that it thinks is out of line, it will discuss the matter with the pricing service and work out an appropriate valuation. Such give and take also help pricing services hone the accuracy of their pricing processes. The SEC expects bond funds that use yield curve pricing as described above to monitor the accuracy of their prices in various ways. Perhaps the most common approach to such monitoring is to compare the price a fund receives upon the sale of a bond from its portfolio to the price the bond was carried at the day prior to sale. If the deviations in such comparisons are both positive and negative, and without a directional bias, the SEC is more likely to conclude that the pricing process is accurate.

When market quotations for a portfolio security are not readily available, as may be the case when the fund is holding illiquid debt securities, a fund must calculate its net

\footnotetext{
168 The Tax Reform Act of 1976 permitted the income on municipal bonds to pass tax-free to holders of municipal bond funds.

${ }^{169}$ In early 1998, there were more than 1000 money market funds in US with net assets of more than $\$ 1.1$ trillion. IMF, 1998.

${ }^{170}$ In most cases, a bond mutual fund will not hold more than 15 percent of its investments in illiquid instruments. While there is no legal requirement to this effect, it was a guideline contained in a guide to the preparation of the investment company registration form. The purpose of the limitation was to ensure that an illiquid portfolio would not inhibit a mutual fund's ability to stand ready to redeem any and all of its shares at any time. While the SEC no longer publishes this guide, it is still used by the industry in preparing registration forms and in operating mutual funds.
} 
asset value by using the fair value of that security, as determined in good faith by the fund's board. The SEC has particularly noted, in connection with Form N-1A, the registration form for mutual funds, that funds must explain the method that they use to value their portfolio securities. Those funds that anticipate the use of fair value pricing as a result, for example, of the absence of a readily available market price, must explain in their disclosure documents the circumstances and effects of its use. The SEC has stated that the fair value of a security is the price which the fund would reasonably expect to receive upon its current sale. The SEC also has stated that funds may not use a "fair value" price that is reached on the theory that the fund is not anticipating "currently" selling the portfolio security. A bond fund, therefore, could not price its securities at par on the basis that it expects to hold the securities until maturity, if the fund could not receive par value if it were to sell the security currently. ${ }^{171}$

Another significant concern that investment companies raise is the potential for conflicts of interest, including, in particular, the possibility of conflicts in affiliate transactions. For example, one concern would be to prevent an affiliate of an investment manager of a bond fund from dumping an unattractive underwriting of debt securities into the fund. Or, an affiliate broker dealer could be taking advantage of the lack of transparency in the marketplace to neglect its obligation of best execution for the fund. In that case, a fund could systematically be getting poor executions and simply not know it. The Investment Company Act and the SEC rules thereunder consequently contain extensive provisions to address the potential conflicts that can arise.

\section{CONCLUSION}

The US fixed income market has flourished for many years. It is one of the oldest and most developed debt markets in the world. It is also one of the most heterogeneous, with the four key market segments - government securities, GSE securities, municipal securities and corporate debt securities - all being relatively large and deep. Except for the antifraud provisions of the US securities laws, the market was unregulated for many years, indeed for most of its history. It is only in recent years that the government, GSE and municipal securities market were regulated at all. Moreover, the regulation, when it came, was not imposed systematically or comprehensively but, rather, was developed in response to various market crises. However, while the debt market itself may have been unregulated, it operated within a larger framework of equity market regulation and enforcement that had a significant impact on its development.

Several aspects of the US experience are particularly noteworthy. First, as mentioned above, the US fixed income market flourished for many years in the absence of regulation. This may well be a testament to the importance of free market forces. Indeed, regulation might have served only to stifle a market that was otherwise

\footnotetext{
${ }^{171}$ As part of its broader investigation of mutual funds that began in the second half of 2003, the SEC reportedly commenced an investigation into possible mispricing at one or more bond funds. See, e.g., SEC to Tackle Bond Fund Mispricing, Financial Times, December 11, 2003.
} 
thriving. Second, when regulation was imposed, it was in response to specific problems that occurred, problems that raised prudential concerns about capital adequacy as well as market integrity concerns about fraud and manipulation. These problems, if not corrected through regulation, could have caused significant instability in the market, particularly as it grew and developed. The undercapitalization of dealers in government securities potentially could cause not only the failure of individual firms, but also a more general systemic disruption in the financial markets as a whole. In fact, the failure of government securities dealers in the 1980s did have a disruptive, domino effect, causing the collapse of other financial institutions. The potential impact of this type of disturbance today, given the size and importance of the US government securities market, and its links with other financial markets, should not be underestimated.

Moreover, the US authorities did not impose a full-scale regulatory scheme on the market all at once. Regulation came in stages, in response to differing demands and priorities. Regulation of the government securities market, for example, focused first on strengthening the intermediaries and only subsequently on improving specific sales practices, enhancing record-keeping and reporting requirements, and broadening participation in the auction process. Similarly, regulation of the municipal securities market also has been an evolving process, with municipal dealers being regulated as early as 1975, and the development of disclosure and transparency rules coming significantly later.

Another striking feature of the regulation of the US debt markets is the multiplicity of regulators. In addition to both the US Treasury and the Federal Reserve, there are separate securities regulators and banking supervisors, including a special regulator for Fannie Mae and Freddie Mac. Self-regulatory organizations also play an important role. This regulatory proliferation may not have contributed to effective debt market regulation in the United States; indeed, regulation may have been effective in spite of the large number of regulators. Nonetheless, the existence of multiple regulatory authorities in the United States has required that there be close and effective cooperation among them. That such cooperation exists is of course is in many ways a function of their history and development.

Despite the rather haphazard evolution of debt market regulation in the United States, it would be incorrect to conclude that the market thrived in the absence of any regulatory framework whatsoever. The broader regulatory context in which the US debt market has operated should not be overlooked. Even in the absence of comprehensive regulation of the debt markets, US authorities historically have taken an expansive approach to equity market regulation, including regulation of the over-the-counter market. In addition, there exists a robust environment for bank supervision. While transactions in government securities and municipal securities were historically exempt from regulation, many of the institutions that dealt in such instruments were subject either to securities regulatory or bank supervisory oversight. Thus, for example, even before prudential rules were expressly imposed on government and municipal securities dealers, those who engaged in broader market business were subject to stringent capital adequacy requirements and an intensive supervisory inspection process. As regulatory schemes developed, the existence of prudential rules, 
internal controls and sales practice requirements were critical elements of the infrastructure, particularly given the absence of a registration requirement for most fixed income securities.

Supporting the US regulatory framework is the authorities' emphasis on enforcement and market integrity. The antifraud provisions of the US securities laws, and their aggressive enforcement by the US SEC, have served the US markets well by creating an atmosphere of confidence that has brought investors into the market and made it easier for firms to raise capital. In addition, the ability of individual investors to bring private actions, including class actions, against issuers, underwriters, and other market participants is an important complement to the enforcement authority of the SEC and plays a significant role in deterring illegal activity. In the absence of prudential regulation, the existence of broad and deep markets must be attributed, at least in part, to the strength of market integrity regulation. Investors have greater confidence that markets are fair when they are enforced by an independent, impartial, and non-political regulator. In addition, the importance of an effective judicial system with an objective judiciary that will enforce regulatory and investor actions should not be underestimated. As regulation and technology increase the transparency of markets to investors as well as to market participants and regulators, the significance of the underlying confidence in fair markets will continue to be ever more important. Indeed, the recent spate of corporate accounting scandals in the United States, raising questions about the integrity of corporate financial statements, including those of the GSEs, as well as other perceived widespread abuses such as in the mutual fund industry, only highlight the importance and potential fragility -- of investor confidence.

In conclusion, regulation of the US fixed income market underscores the importance of a home-grown form of regulation, one that is developed by and adapted to the type of market and political and legal infrastructure that exists. In addition, the authority of the regulator, its resources, and whether its rules can be legally enforced through an impartial judiciary all are important influences on the effectiveness of regulation. Finally, what the US experience demonstrates the most is the dynamic nature of regulation. Regulation must, necessarily, be responsive to market developments. Regulators and financial authorities cannot afford to become complacent, even when the markets are strong. Markets do not stand still; they are constantly evolving, particularly with the advent of globalization and technology. US regulators have been required to do no less.

\section{LIST OF REFERENCES}


Bartolini, L. and Cottarelli, Carlo, Designing Effective Auctions for Treasury Securities, Current Issues in Economics and Finance 3/9, FRBNY, www.ny.frb.org, 1997

Beller, Alan, Remarks at Bond Market Association Annual Meeting, New York, New York, April 2003

BIS Study Group on Fixed Income Markets, The Changing Shape of Fixed Income Markets, BIS Papers No. 5, October 2001

Bond Markets Association, Bond Markets 2000: A Conceptual Framework for Efficient Regulation of the Fixed Income Markets, BMA Member Exposure Draft, October 1998

Bond Markets Association, Uniform Practices for the Clearance and Settlement of Mortgage-Backed Securities and Other Related Securities, 1990

Burnham, James B., The Government Securities Act of 1986: A Case Study of the Demand for Regulation, Regulation: The CATO Review of Business \& Government, www.cato.org, Washington DC, Summer 1990

Carey, Mark and Prowse, Stephen, The Economics of the Private Placement Market, Board of Governors of the Federal Reserve, Staff Studies 166, December 1993

Chaplinsky, Susan and Ramchand, Latha, The Impact of SEC Rule 144A on Corporate Debt Issuance by Foreign Firms, www.faculty.darden.virginia.edu, October 2000

Committee on Payment and Settlement Systems, Payment and Settlement Systems in Selected Countries, Part 15, Payment Systems in the United States, BIS, May, 2003

Dewar, Helen and Berry, John M., White House Urges Senate to Raise Debt Ceiling Soon, Washingtonpost.com, May 2003

Dupont, Dominique and Sack, Brian, The Treasury Securities Market: Overview and Recent Developments, Federal Reserve Bulletin, December 1999

El Daher, Samir, Credit Ratings: An Introduction (and the Case of Sub-Sovereign Ratings), Infrastructure Notes, Urban No. FM-8c, The World Bank, July 1999

Fabozzi, Frank J., Handbook of Fixed Income Securities, $6^{\text {th }}$ Edition, McGraw Hill, 2001

Federal Reserve Board of New York, Fedpoint 2: Primary Dealers, www.ny.frb.org

Fleming, Michael J. and Garbade, Kenneth D., When the Back Office Moved to the Front Burner: Settlement Fails in the Treasury Market after 9/11, FRBNY Policy Review, November 2002 
Haines, Martha Mahan, Disclosure in the Municipal Market: Fundamental Concepts for Issuers, www.sec.gov, Washington DC, September, 2000

IMF and World Bank, Guidelines for Public Debt Management, 2001

International Organization of Securities Commissions, Objectives and Principles of Securities Regulation, Annex III, www.iosco.org, May, 2003

International Organization of Securities Commission, Transparency and Market Fragmentation, Technical Committee, November 2001

Landis, James M., The Legislative History of the Securities Act of 1933, 28 Geo. Wash. L. Rev. 29, 37 (1959) quoted in Joel Seligman, Gotterdammerung for the Securities Act?, 75 Wash. U. L. Q. 887, fn 16 (Summer 1997)

Lehmann, Richard, Mutual Funds can be Dangerous, Forbes.com, April 2002

Levitt, Arthur, The Importance of Transparency in America's Debt Market, Speech by SEC Chairman at the Media Studies Center, New York City, September 1998.

Livingston, Miles and Zhou, Lei, The Impact of Rule 144A Debt Offerings upon Bond Yields and Underwriter Fees, Bowne Securities Connect, Abstract from Winter 2002 Financial Management, pp. 5 -27, www.bowne.com, March 2003

Lucier, Jennifer A., Clearance \& Settlement Workshop, SEC International Institute for Securities Market Development, Washington DC, 2003

Maco, Paul S., Building a Strong Subnational Debt Market: A Regulator's Perspective, Richmond Journal of Global Law \& Business, Vol 2:1, 2001

Maco, Paul S., Securities Laws and the Municipal Market: Points Every Issuer Should Keep in Mind, Remarks before the NY State Government Finance Officers Association, West Point, New York, October 1999.

Malvey, P., Uniform Price Auctions: Evaluation of the Treasury Experience, Office of Market Finance, US Department of Treasury, Washington DC, 1995

Mathieson, Donald J. and Schinasi, Garry J., The Changing Structure of the Major Government Securities Markets: Implications for Private Financial Markets and Key Policy Issues, Chapter 4, Development, Prospects \& Key Policy Issues, IMF International Capital Markets, August 2001

Miller, George, Debt Markets in the United States, The Bond Market Association, SEC International Institute for Securities Market Development, Washington DC, 2003 
Nazareth, Annette L., Remarks before the MSRB Disclosure Forum II, www.sec.gov, January 2001

OECD, Government Securities \& Debt Management in the 1990s, Paris, 1993

Pitt, Harvey L, On Fannie Mae/ Freddie Mac, Statement by SEC Chairman, Washington DC, July 2002

Reid, Brian, Growth and Development of Bond Mutual Funds, Perspective, Investment Company Institute, 3/2, June 1997

Schinasi, Garry J. and Smith, R. Todd, Fixed Income Markets in the US, Europe \& Japan: Some Lessons for Emerging Markets, IMF Working Paper WP/98/173, December 1998

Strahota, Robert D., Developing a Regulatory Framework for Fixed-Income Securities Markets, Washington DC, January 2000

US SEC, Report on the Role and Function of Credit Rating Agencies in the Operation of the Securities Markets, As Required by Section 702(b) of the Sarbanes-Oxley Act of 2002, www.sec.gov, Washington DC, January 2003

US SEC, Rating Agencies and the Use of Credit Ratings under the Federal Securities Laws, SEC Concept Release No. 33-8236, 34-47972, IC-26066, June 2003

US SEC, Report to the Congress: The Impact of Recent Technological Advances on the Securities Markets, www.sec.gov, Washington DC, September 1997

US SEC and Federal Reserve Board, Interagency White Paper on Structural Change in the Settlement of Government Securities: Issues and Options, SEC Concept Release No. 34-45879, Washington DC, May, 2002

US SEC, Federal Reserve, NY State Banking Department and Office of the Comptroller of the Currency, Staff Discussion Note: Summary of "Lessons Learned" from Events of September 11 and Implications for Business Continuity, Prepared for Meeting on 26 February 2002, at FRBNY, www.sec.gov/divisions/marketreg, February 2002

US SEC, Federal Reserve Board and Office of the Comptroller of the Currency, Sound Practices to Strengthen the Resilience of the US Financial System, SEC Release No. 34 47638; Washington DC, April 2003

US SEC, Federal Reserve Board and Department of the Treasury, Joint Study of the Regulatory System for Government Securities, www.publicdebt.treas.gov, Washington DC, March 1998 
US SEC, Department of the Treasury, Office of Federal Housing Enterprise Oversight, Staff Report on Enhancing Disclosure in the Mortgage-Backed Securities Markets, www.sec.gov, Washington DC, January 2003

Willis, Clint, All Bond Funds are not Really Equal, Reuters.com, May 2003

World Bank and IMF, Developing Government Bond Markets: A Handbook, Washington DC, 2001

Zipf, Robert, How the Bond Market Works, 3d Edition, New York Institute of Finance, New York, New York, 2002 